\title{
Great earthquakes and subduction along the Peru trench
}

\author{
Susan L. Beck * and Larry J. Ruff \\ Dept. of Geological Sciences, University of Michigan, Ann Arbor, Michigan 48109 (U.S.A.)
}

(Received March 7, 1988; revision accepted December 14, 1988)

Beck, S.L. and Ruff, L.J., 1989. Great earthquakes and subduction along the Peru trench. Phys. Earth Planet. Inter., 57: 199-224.

Subduction along the Peru trench, between 9 and $15^{\circ} \mathrm{S}$, involves both large interplate underthrusting earthquakes and intraplate normal-fault earthquakes. The four largest earthquakes along the Peru trench are, from north to south, the $1970\left(M_{\mathrm{w}}=7.9\right)$ intraplate normal-fault earthquake, and the interplate underthrusting earthquakes in 1966 $\left(M_{\mathrm{w}}=8.0\right), 1940(M=8)$ and $1974\left(M_{\mathrm{w}}=8.0\right)$. We have studied the rupture process of these earthquakes and can locate spatial concentrations of moment release through directivity analysis of source-time functions deconvolved from long-period P-wave seismograms. The 1966 earthquake has a source duration of $45 \mathrm{~s}$ with most of the moment release concentrated near the epicenter. Two intraplate normal-fault events occurred in $1963\left(M_{\mathrm{s}}=6.7\right.$ and 7.0$)$, at the down-dip edge of the 1966 dominant asperity. The 1940 earthquake is an underthrusting event with a simple source time function of $30 \mathrm{~s}$ duration that represents the rupture of a single asperity near the epicenter. The 1974 earthquake has a source duration of 45-50 $\mathrm{s}$ and two pulses of moment release. This earthquake has a bilateral rupture with the first pulse of moment release located northwest of the epicenter and the second pulse of moment release located southeast of the epicenter. Both pulses of moment release occur on the northern half of the aftershock area. The 1970 earthquake is one of the largest intraplate normal-fault earthquakes to occur in a subduction zone and has a moment release comparable with many large underthrusting events. The aftershocks for the 1970 earthquake form two distinct clusters, the smaller cluster near the epicenter has focal mechanisms characterized by down-dip tension but the second aftershock cluster, located $80 \mathrm{~km}$ southeast of the epicenter, has focal mechanisms characterized by down-dip compression. The P-waves for the main shock can be modeled as two sources with different focal mechanisms and depths similar to the two clusters of aftershocks. The first event has a down-dip tensional focal mechanism and is followed $40 \mathrm{~s}$ later by a distinct second event located $80 \mathrm{~km}$ southeast of the epicenter with a down-dip compressional focal mechanism and a somewhat shallower depth than the first event. The observable directivity indicates that the second source is located at the second cluster of aftershocks that have down-dip compressional focal mechanisms. The occurrence of both down-dip tensional and compressional focal mechanisms may be explained by extreme 'unbending' stresses associated with the anomalous slab geometry. The unusually large size of the 1970 earthquake may also be related to the subduction of the Mendaña fracture zone.

The historic earthquake record along the Peru trench indicates that the previous event in 1746 was much larger than any of the three underthrusting earthquakes this century. The 1746 earthquake may have ruptured the entire segment in a multiple asperity earthquake. Thus, the mode of rupture along the Peru coast has changed between successive earthquake cycles.

\footnotetext{
* Present address: Institute of Geophysics \& Planetary Physics and Earth Sciences Dept., Lawrence Livermore National Laboratory, Livermore, CA 94550, U.S.A.
}

0031-9201/89/\$03.50 C 1989 Elsevier Science Publishers B.V.

\section{Introduction}

The subduction zone along the central Peru trench, between 9 and $15^{\circ} \mathrm{S}$, is a major plate 

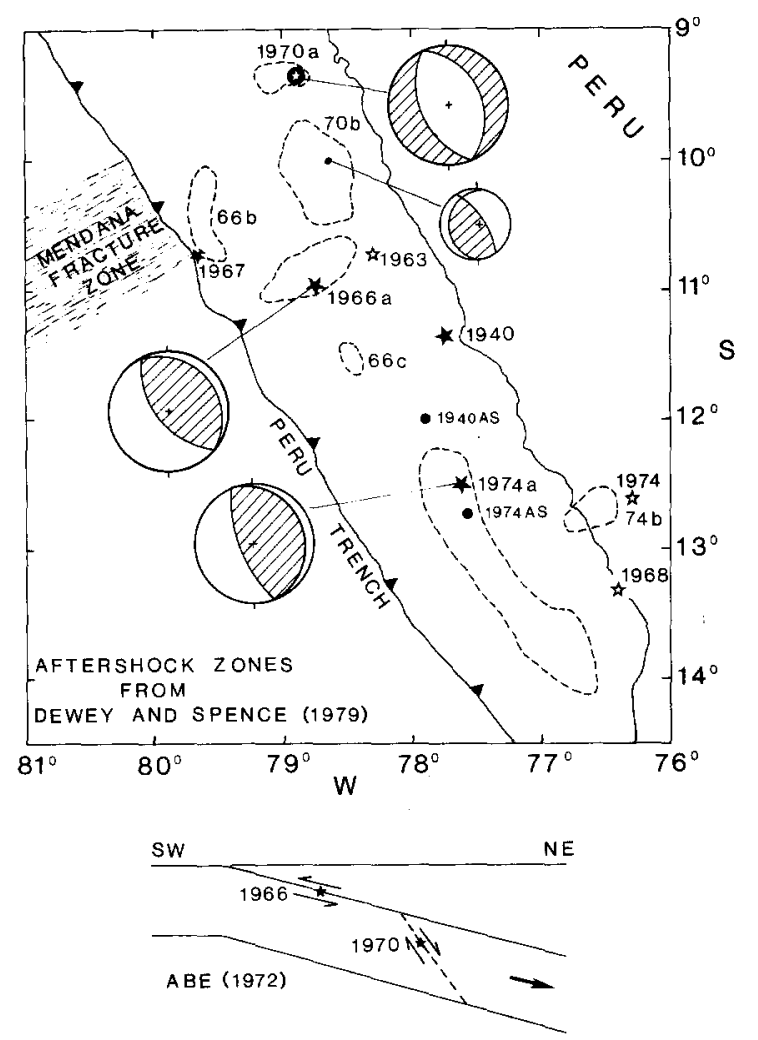

Fig. 1. Map of the central Peru subduction zone showing the locations of the major earthquakes. The solid stars are earthquakes with underthrusting focal mechanisms or down-dip compressional focal mechanisms. The open stars are events with down-dip tensional focal mechanisms. The aftershock clusters are from Dewey and Spence (1979). 1940AS and 1974AS are the locations of the largest aftershocks $(M \sim 7)$ for the 1940 and 1974 main shocks.

boundary capable of generating devastating interplate and intraplate earthquakes (Fig. 1). The two largest earthquakes are underthrusting events in $1966\left(M_{\mathrm{w}}=8.1\right)$ and $1974\left(M_{\mathrm{w}}=8.0\right)$ that represent subduction of the Nazca plate along the Peru trench (Fig. 1). North of the 1966 event an unusually large normal-fault earthquake occurred in 1970 $\left(M_{\mathrm{w}}=7.9\right)$ within the down-going Nazca plate. This event caused by far the most damage and loss of life of the three large Peru earthquakes, and in fact is one of the largest normal-fault earthquakes this century. In addition, another $M$ $=8$ (Gutenberg and Richter, 1954) event occurred near the Peru coast in 1940 , about which little is known.
This segment of the down-going Nazca plate is bounded in the north by the Mendaña fracture zone and to the south by the Nazca ridge. The dip of the descending Nazca slab is unusually shallow at intermediate depths, and has been correlated with the pronounced absence of Quaternary volcanism on the overriding South American plate (Barazangi and Isacks, 1976). The slab dips from 10 to $30^{\circ}$ to a depth of $100 \mathrm{~km}$ and then becomes horizontal beneath the South American continent for nearly $700 \mathrm{~km}$ (Barazangi and Isacks, 1979; Hasegawa and Sacks, 1981).

We have characterized the rupture process of the four largest earthquakes along the Peru trench since 1940 in order to determine the spatial heterogeneity and the lateral interaction of the dominant asperities. Relocated hypocenters for this segment of the Peru subduction zone reveal distinct clusters of aftershocks associated with the largest earthquakes (Dewey and Spence, 1979) (Fig. 1). These well-located events allow us to compare the details of the rupture process and spatial moment release of the main shocks with the occurrence of aftershocks.

\section{Data and methods}

WWSSN long-period vertical and horizontal $P$ and PP seismograms were used to analyze post1963 earthquakes. For the 1940 earthquake and its largest aftershock we used $\mathrm{P}$ and PP phases from a variety of instruments. Because many of the vertical-component $P$ waves are off-scale for large to great earthquakes, many horizontal components are used. Horizontal receiver factors were determined by comparing horizontal and vertical component amplitudes for the first few P-wave cycles or by using a theoretical correction (Bullen, 1963) if the vertical component went off-scale immediately. We have also used diffracted P-waves in order to increase the azimuthal coverage. Because we do not correct for core diffraction effects, the seismic moment determined from a diffracted P-wave underestimates the seismic moment.

Source-time functions were obtained using the deconvolution method of Ruff and Kanamori 
TABLE 1

Earthquake parameters ${ }^{c}$

\begin{tabular}{|c|c|c|c|c|c|c|}
\hline Date & $\begin{array}{l}\text { Latitude } \\
\left({ }^{\circ} \mathrm{S}\right)\end{array}$ & $\begin{array}{l}\text { Longitude } \\
\left({ }^{\circ} \mathrm{W}\right)\end{array}$ & $M_{\mathrm{s}}$ & Depth & Strike, Dip, Rake ( $\left.{ }^{\circ}\right)$ & Reference $^{b}$ \\
\hline $24 / 5 / 40$ & 11.22 & 77.79 & 8 & $10-30^{a}$ & $340,20,90$ & This study \\
\hline $24 / 5 / 40$ & 11.84 & 77.96 & 7 & $20^{a}$ & $340,20,90$ & This study \\
\hline $17 / 9 / 63$ & 10.78 & 78.26 & 6.7 & 64 & $187,43,-60$ & S75 \\
\hline $24 / 9 / 63$ & 10.75 & 78.23 & 7.0 & 75 & $91,25,-141$ & S75 \\
\hline $17 / 10 / 66$ & 10.92 & 78.79 & 8.0 & $10-30^{a}$ & $335,12,90$ & A72 \\
\hline $3 / 9 / 67$ & 10.69 & 79.74 & 7.0 & 28 & $0,60,140$ & S75 \\
\hline $28 / 9 / 68$ & 13.21 & 76.33 & 6.0 & 80 & $122,17,-125$ & S75 \\
\hline $31 / 5 / 70$ & 9.36 & 78.87 & 7.8 & $<50^{\mathrm{a}}$ & $340,53,-90$ & A72 \\
\hline $2 / 6 / 70$ & 9.87 & 78.89 & $5.7\left(m_{\mathrm{b}}\right)$ & 54 & $320,65,68$ & S75 \\
\hline $4 / 6 / 70$ & 9.96 & 78.68 & $5.8\left(m_{\mathrm{b}}\right)$ & 55 & $330,74,78$ & S75 \\
\hline $2 / 7 / 70$ & 10.28 & 78.66 & $5.8\left(m_{\mathrm{b}}\right)$ & 47 & $158,86,82$ & S75 \\
\hline $5 / 1 / 74$ & 12.42 & 76.31 & 6.6 & 93 & $18,55,-65$ & L89 \\
\hline $3 / 10 / 74$ & 12.39 & 77.66 & 7.8 & $10-25^{\mathrm{a}}$ & $340,17,90$ & G.S. \\
\hline $9 / 11 / 74$ & 12.64 & 77.56 & 7.2 & $20-25^{a}$ & $340,17,90$ & This study \\
\hline
\end{tabular}

andicates depths determined in this study.

b References for focal mechanisms: S75 (Stauder, 1975), A72 (Abe, 1972), L89 (Lay et al., 1989), G.S. (Gordon Stewart, personal communication).

c Locations and depths are from Dewey and Spence (1979) except for the locations of the 1940 earthquakes, which are from J. Dewey (personal communication).

(1983). The Green's functions included the direct $\mathrm{P}, \mathrm{pP}$ and $\mathrm{sP}$ surface reflections, and ocean layer multiple reflections where appropriate. The PP phases were Hilbert transformed following the method outlined by Lynnes and Ruff (1985) before deconvolving to obtain a source-time function. Dependent upon the earthquake size, a distributed source or a point source was used.

For the largest earthquakes we have constrained the depth using the method described by Christensen and Ruff (1985), where the best depth concentrates the moment release toward the beginning of the deconvolved source-time function. The half-absolute moment time $\left(T_{1 / 2}\right)$ of a sourcetime function is a measure of the moment concentration. $T_{1 / 2}$ is defined as the time difference between the start of the source function and the time at which half of the summed absolute value of the time function is achieved (Christensen and Ruff, 1985). When the depth is overestimated the source functions exhibit periodic ringing in the latter part of the source function. We will show $T_{1 / 2}$ versus depth curves for some of the earthquakes.
Observable directivity, associated with consistent features on the source-time functions, is used to determine the spatial location of the moment release on the fault plane. This technique has been applied successfully in studies of the rupture process of numerous earthquakes (for examples, see Beck and Ruff (1984), and Schwartz and Ruff (1985)). For most of the earthquakes we have used focal mechanisms from the literature. Table 1 lists the earthquake parameters discussed in this paper.

\section{The 1974 earthquake}

The 3 October 1974 earthquake $\left(M_{\mathrm{w}}=8.0\right)$ occurred in a segment along the Peru trench recognized by Kelleher (1972) as a seismic gap. The 1974 earthquake has an underthrusting focal mechanism of strike $340^{\circ}$, dip $17^{\circ}$, rake $90^{\circ}$, and a seismic moment of $15 \times 10^{27}$ dyn $\mathrm{cm}$, determined from surface waves (Gordon Stewart, personal communication). The main shock was followed by a large aftershock $\left(M_{\mathrm{s}}=7.2\right)$ on 9 November 1974 , located $\sim 30 \mathrm{~km}$ south-east of 

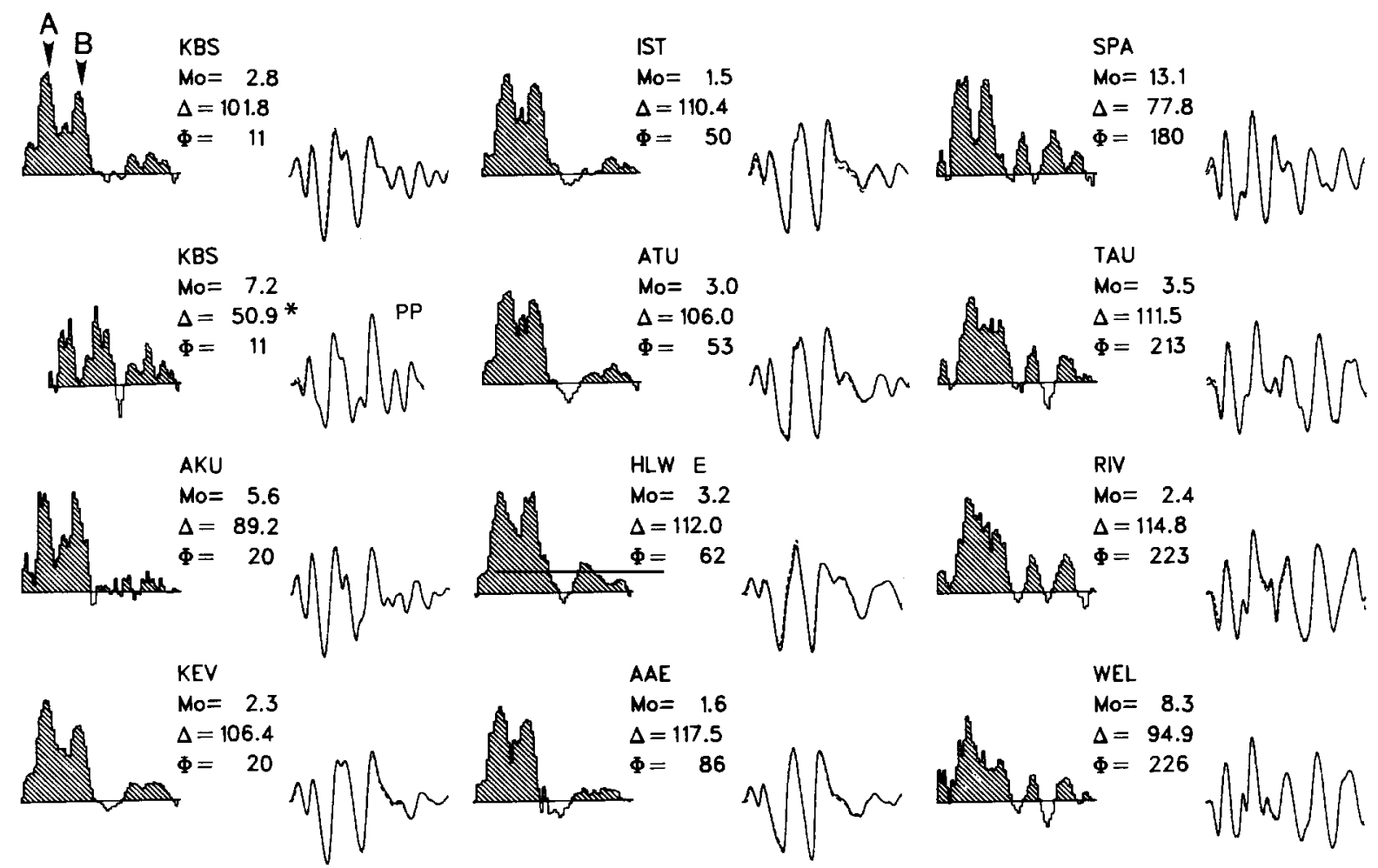

KEV
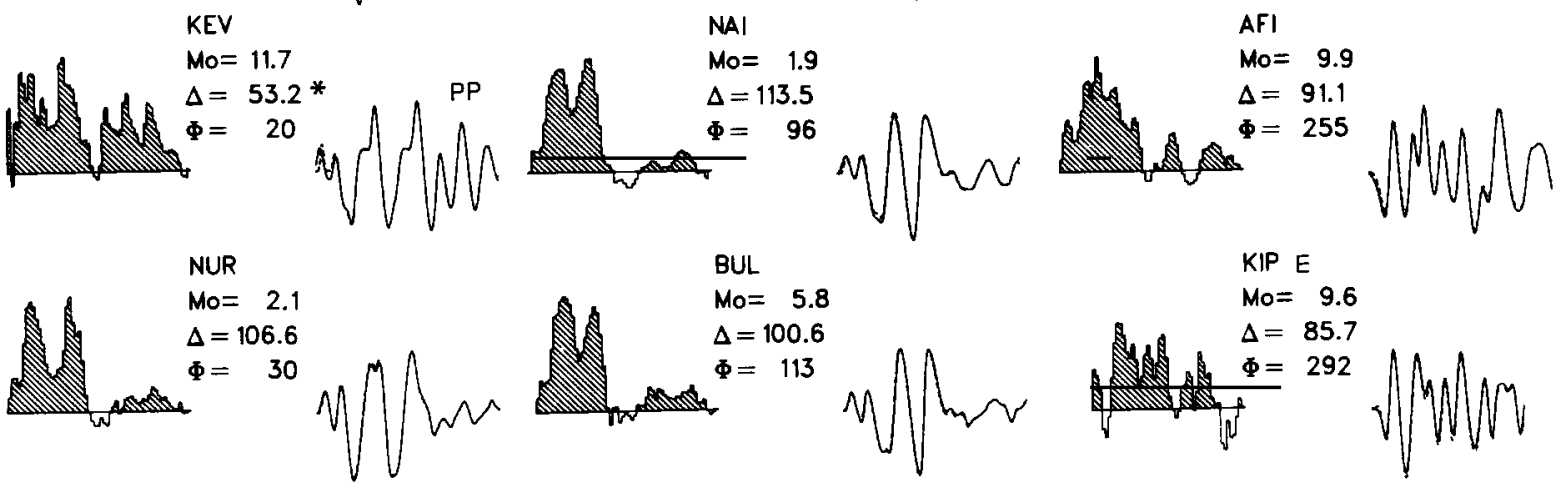

$\mathrm{Mo}=1.9$

$\Delta=113.5$

$=96$
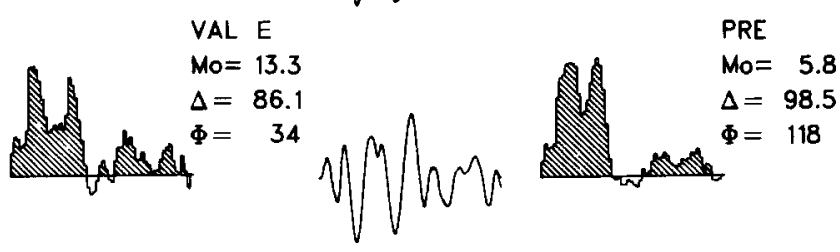

PRE
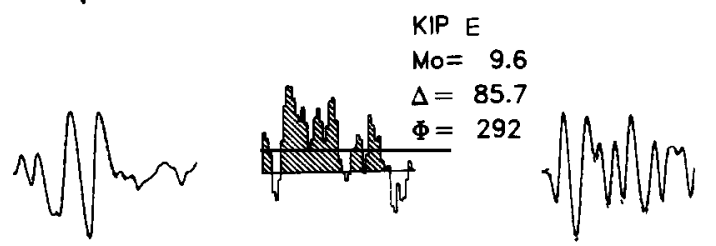

KIP E

Mo $=9.6$

LON
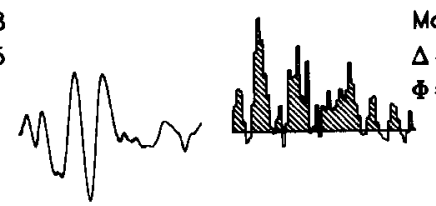

Mo $=4.1$

$\Delta=70.8$

$\Phi=329$

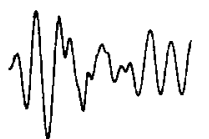

STU
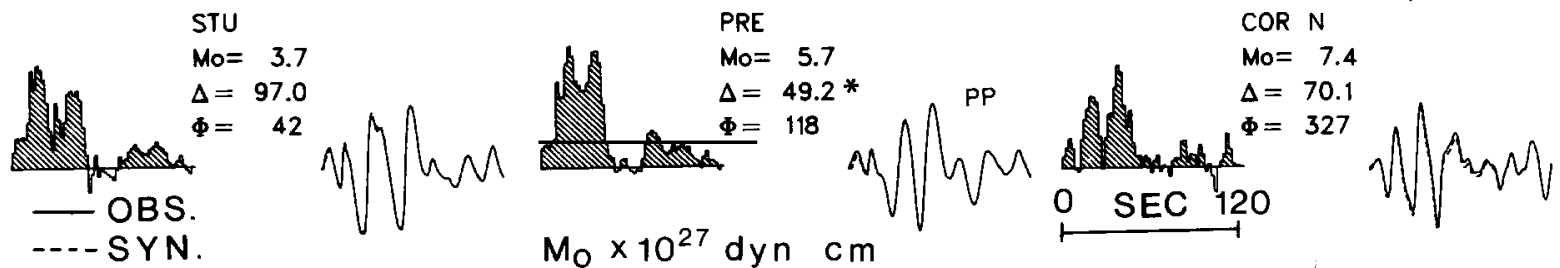

Fig. 2. Source-time functions for the 3 October 1974 earthquake. $N$ and $E$ indicate that north-south and east-west components were used because the vertical components were not available. The solid trace is the observed seismogram and the dashed trace is the synthetic seismogram for the source-time function shown for each station. The P-waves were deconvolved using a distributed depth of $10-25 \mathrm{~km}$. The * indicates a PP phase was used and the distance shown is one-half the epicentral distance. The source-time functions show two distinct pulses of moment release with truncations labeled A and B, respectively. 
the main shock epicenter. The relocated 30-day aftershocks for the main shock indicate two distinct regions (Dewey and Spence, 1979). The main cluster of aftershocks is a narrow strip $40 \mathrm{~km}$ in width and $240 \mathrm{~km}$ in the NW-SE direction (Fig. 1). The main-shock epicenter is approximately 50 $\mathrm{km}$ from the northwestern end of this elongate aftershock region. The second smaller cluster of aftershocks is down-dip and $80 \mathrm{~km}$ inland of the main cluster, and probably within the down-going Nazca plate and not part of the actual underthrusting interface (Dewey and Spence, 1979). This indicates that there was some interaction between the underthrusting zone and the stress field within the down-going plate.

We deconvolved $\mathbf{P}$ and PP phases to obtain source-time functions for the 1974 earthquake using a distributed source between 10 and $25 \mathrm{~km}$ (Fig. 2). For depths below $20-25 \mathrm{~km}$, the source functions exhibit the periodic ringing characteris-

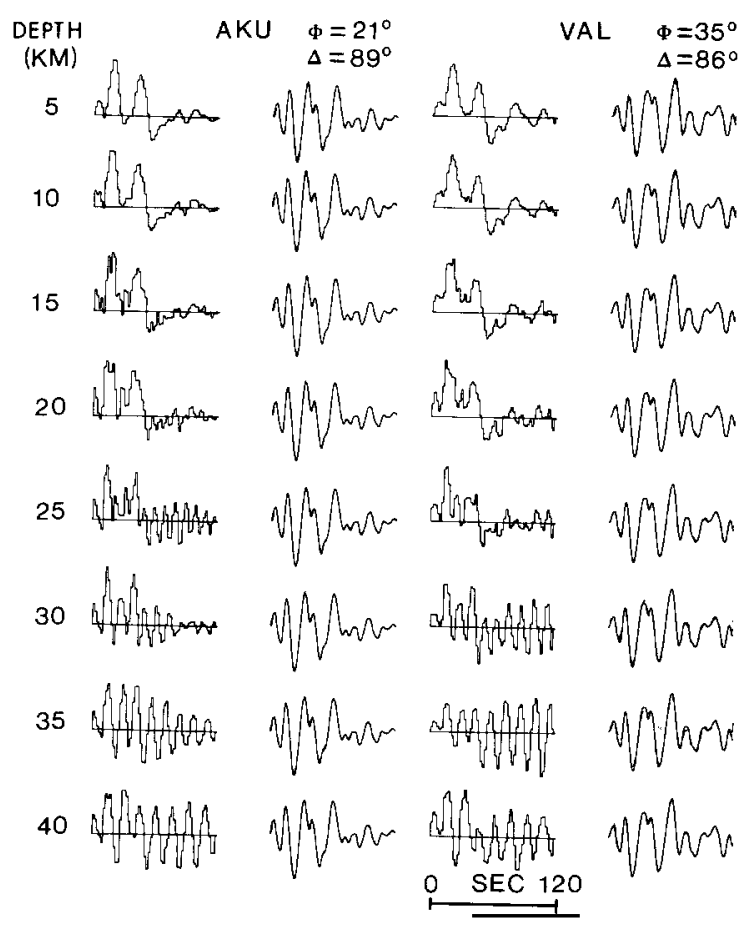

Fig. 3. Source-time functions for the 3 October 1974 earthquake for stations AKU and VAL deconvolved at depths from 5 to $40 \mathrm{~km}$. Notice the increase in ringing of the latter part of the source-time function at depths below $25 \mathrm{~km}$. tic of depth overestimation (Fig. 3). Figure 3 shows source functions deconvolved at depths between 5 and $40 \mathrm{~km}$ for stations AKU and VAL. The upper depth bound for large underthrusting earthquakes is not easily resolvable. Consequently, we use an upper depth of $10 \mathrm{~km}$ based on the aftershock area. The source-time functions for this earthquake have two pulses of moment release and a total duration of $45-50 \mathrm{~s}$ (Fig. 2). The undiffracted $\mathrm{P}$-waves yield an average seismic moment of $9 \times 10^{27}$ dyn $\mathrm{cm}$. This is less than the surface-wave moment of $15 \times 10^{27} \mathrm{dyn} \mathrm{cm}$ and indicates that there may be a long-period component of moment release not resolved from the P-waves.

The truncations of the two pulses of moment release (labeled A and B in Fig. 2) can be spatially located based on the azimuthal directivity. The best rupture direction is along strike, as would be expected from the elongate aftershock area (Fig. 4). The 1974 earthquake had a bilateral rupture with the truncation of the first pulse of moment release located $\sim 40 \mathrm{~km}$ northwest of the epicenter and the truncation of the second pulse of moment release located $\sim 60 \mathrm{~km}$ southeast of the epicenter (Fig. 4). Thus, we conclude that the majority of the moment release occurred only on the northwestern half of the elongate aftershock area.

\subsection{Tomographic inversion}

To determine quantitatively the moment release along the fault, we have used the inversion method devised by Ruff (1987). We have inverted the previously determined source-time functions for a space-time image of the rupture. This method uses a priori estimates of the rupture azimuth and velocity and iteratively determines the moment-release distribution that best fits the observed time functions in a least-squares sense. A large number of rupture azimuths and velocities can be tested easily and quickly and the best overall fit to the time functions gives the best choice of rupture parameters. The data misfit error is measured by $e$, which is the ratio of the error vector length to the data vector length (Ruff, 1987). 
We first tested a fault with a bilateral rupture from -200 to $+200 \mathrm{~km}$ centered around the epicenter, discretized with a $10-\mathrm{km}$ spatial interval, and 120-s source time function duration. To determine the best rupture azimuth and velocity the source-time functions were baseline normalized to have zero moment. Synthetic sourcetime functions were produced for each model image. The best rupture azimuths are between 140 and $180^{\circ}$ for all choices of rupture velocity (Fig. $5)$. The rupture velocity is more difficult to de-
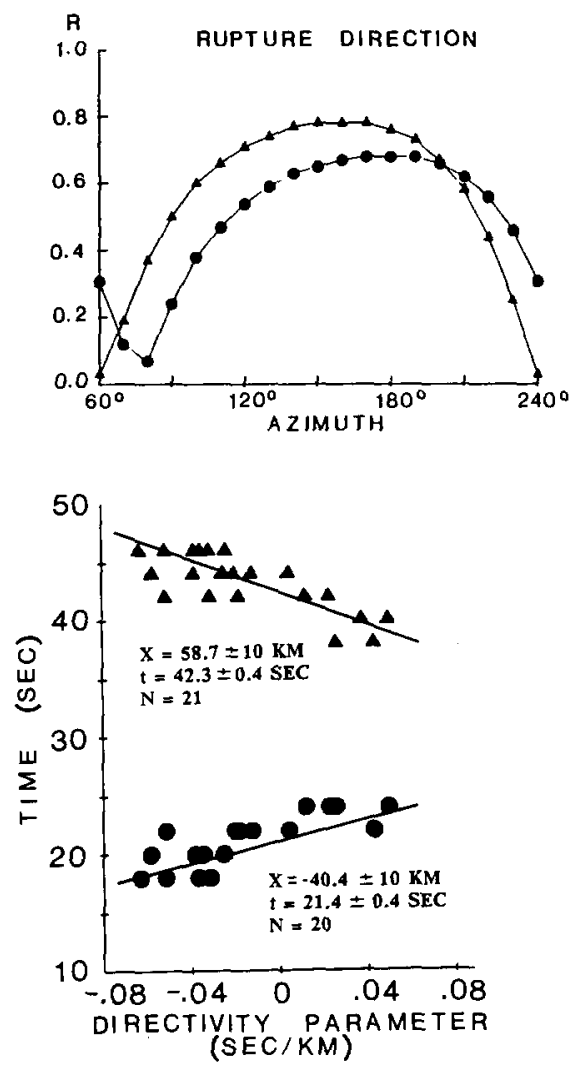

Fig. 4. Best fit (least squares) straight line for delay time $\left(T_{i}\right)$ versus the directivity parameter $\left(\Gamma_{i}\right)$ for the two features (A and $B$ ) picked on the source-time function for the 3 October 1974 earthquake. The directivity parameter is the product of the ray parameter and the cosine of the angle between station azimuth and the assumed rupture azimuth. The slope of the line $(X)$ gives the horizontal distance and the $y$-intercept $(t)$ gives the actual delay time relative to the initiation of rupture. The best rupture directions are $140-180^{\circ}$ as shown by the above plot of correlation coefficient $(R)$ of the best fit straight line as a function of rupture azimuth.

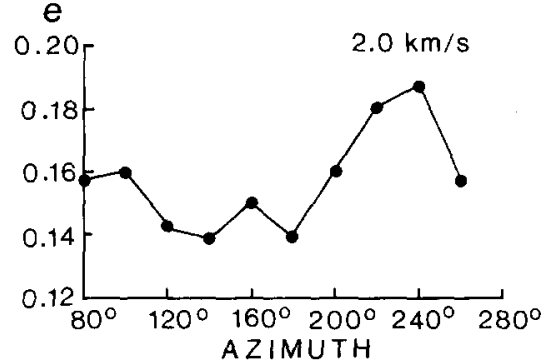

Fig. 5. Rupture azimuth based on the tomographic inversion for the 3 October 1974 earthquake. Plot of the parameter $e$, which is the error vector length divided by the data vector length versus assumed rupture azimuths between 80 and $270^{\circ}$. The smallest value of $e$ corresponds to the best rupture azimuth.

termine and we could not reliably distinguish between rupture velocities of $1.5-2.5 \mathrm{~km} \mathrm{~s}^{-1}$. We repeat the inversion using the best rupture azimuth $\left(180^{\circ}\right)$, a rupture velocity of $2.0 \mathrm{~km} \mathrm{~s}^{-1}$, and source-time functions with a seismic moment of $15 \times 10^{27} \mathrm{dyn} \mathrm{cm}$ (Fig. 6). The fault is restricted to -50 and +200 (positive toward the southeast) around the epicenter. The first iteration model image has the moment release distributed symmetrically about the epicenter, but subsequent iterations always produced an asymmetrical momentrelease (Fig. 6). Figure 6 shows our final rupture image for the 1974 earthquake. The first pulse of moment release occurred northwest of the epicenter with the truncation at $50 \mathrm{~km}$. The second pulse of moment release occurred southeast of the epicenter and ends at $\sim 80 \mathrm{~km}$. The results of the inversion are very similar to our previous directivity results and indicate a bilateral rupture. The previous directivity results indicated a slightly slower rupture velocity than $2.0 \mathrm{~km} \mathrm{~s}^{-1}$ and hence gave distances of 40 and $60 \mathrm{~km}$ for the two truncations rather than $50 \mathrm{~km}$ and $80 \mathrm{~km}$, respectively.

We also computed the time-integrated moment density along the fault zone for a total seismic moment of $15 \times 10^{27}$ dyn $\mathrm{cm}$ (Fig. 7). We can relate the seismic moment to displacement by the formula $M o=\mu A D$, where $\mu$ is the shear modulus $\left(5 \times 10^{11} \mathrm{dyn} \mathrm{cm}^{-2}\right), A$ is the fault area and $D$ is the displacement. The width of the fault area is usually an unknown parameter, but in this case the aftershocks define a fairly narrow width of 40 

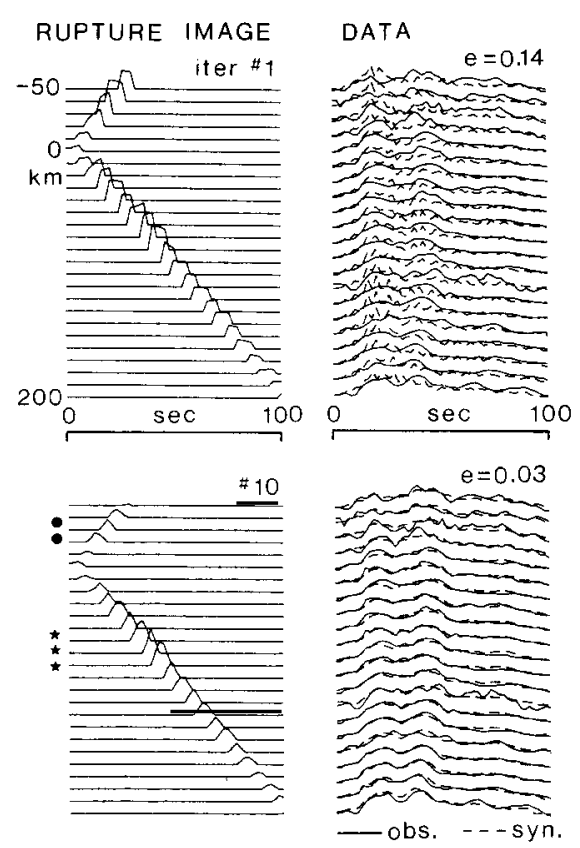

Fig. 6. Overall best rupture image of the 3 October 1974 earthquake from the tomographic inversion. The model image has spatial extent from $-50 \mathrm{~km}$ to $+200 \mathrm{~km}$ with a spacing of $10 \mathrm{~km}$, a rupture azimuth of $\mathrm{N} 180^{\circ} \mathrm{E}$, and a rupture velocity of $2.0 \mathrm{~km} \mathrm{~s}^{-1}$. The epicenter is at $0 \mathrm{~km}$. The observed and synthetic data for the model are shown on the right. The. source-time functions are normalized to a seismic moment of $15 \times 10^{27} \mathrm{dyn} \mathrm{cm}$. The normalized error vector length decreases from 0.14 to 0.03 from the first to the tenth iteration. The tomographic inversion indicates a bilateral rupture.

MOMENT DENSITY / SEISMIC DISPLACEMENT

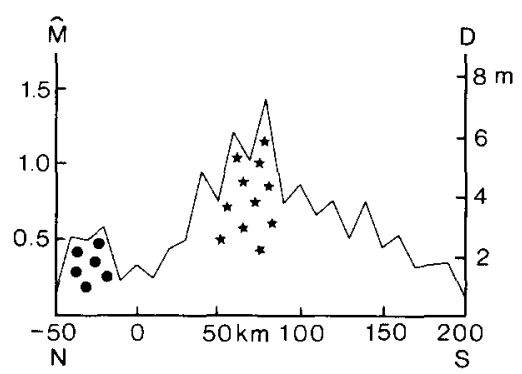

Fig. 7. Moment density/seismic displacement along the fault from the best rupture image of the 3 October 1974 earthquake (Fig. 6). The moment density function $M$, is the time integral of the traces in Fig. 6 and has units of $10^{27} \mathrm{dyn} \mathrm{cm} \mathrm{km}^{-1}$. The seismic displacement along the fault (in meters) is obtained by dividing the moment density by $(\mu \mathrm{W})$ with $\mu=5 \times 10^{11}$ dyn $\mathrm{cm}^{-2}$ and $W=40 \mathrm{~km}$. The two dominant asperities are shown by the stars and dots.

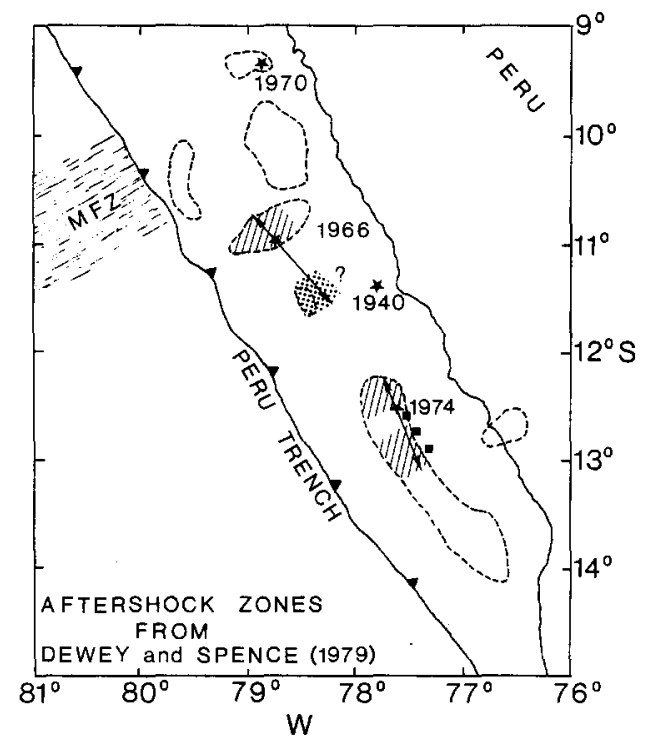

Fig. 8. Map of the spatial moment release for the 17 October 1966 and 3 October 1974 earthquakes. The hachured regions represent the dominant asperities for each earthquake. The dotted region southeast of the 1966 epicenter represents a less reliable region of moment release for the 1966 earthquake. The square symbols adjacent to the 1974 aftershock zone are earthquakes occurring, from northwest to southeast, on 27 September 1974, 24 December 1973 and 3 October 1971.

$\mathrm{km}$. The average displacement over the entire fault length of $240 \mathrm{~km}$ is $3 \mathrm{~m}$. However, the moment release is not uniform as shown in Fig. 7, where the largest moment release occurs $70-80 \mathrm{~km}$ southeast of the epicenter and corresponds to a displacement of $7 \mathrm{~m}$. We conclude that the dominant asperity for the 1974 earthquake occurs on the northwestern half of the aftershock area.

Dewey and Spence (1979) noted an increase in seismicity prior to the 1974 main-shock rupture at the down-dip edge of the future rupture zone (Fig. 8). The largest three events occurred on 27 September $1974\left(m_{\mathrm{b}}=5.0\right), 24$ December $1973\left(m_{\mathrm{b}}=\right.$ 5.4) and 3 October $1971\left(m_{\mathrm{b}}=5.2\right.$ (Fig. 8). We are unable to determine reliable focal mechanisms for these earthquakes. These events occurred between the epicenter and $60 \mathrm{~km}$ to the southeast along the down-dip edge of the future main-shock rupture zone. This is exactly along the down-dip edge of the 1974 main shock asperity (Fig. 8). This precursory activity may be reflecting the strong coupling of the asperity region. 
Two intraplate down-dip tensional events occurred prior to the 1974 main shock at intermediate depths on 28 September 1968 and 5 January 1974 (Fig. 1). The 28 September 1968 earthquake occurred down-dip of the southern part of the 1974 main-shock rupture area. The 5 January 1974 event occurred near the 74b cluster of aftershocks. Astiz et al. (1989) have suggested that the stresses at intermediate depths down-dip of the underthrusting zones are temporally related to the coupling in the underthrusting region. Prior to the occurrence of large underthrusting earthquakes the interface boundary is locked and tensional stresses occur down-dip at intermediate depths. After the occurrence of large underthrusting events the down-dip region is in compression. The two down-dip tensional events may reflect this increase in tensional stresses prior to the 1974 underthrusting earthquake. On 28 March 1982, a down-dip compressional earthquake $\left(M_{\mathrm{s}}=6.3\right.$, depth $=109 \mathrm{~km}$ ) occurred down-dip of the 1974 main shock (Astiz et al., 1989).

\subsection{The 9 November 1974 aftershock}

On 9 November 1974 a large $\left(M_{\mathrm{s}}=7.2\right)$ aftershock occurred within the main aftershock area $30 \mathrm{~km}$ southeast of the main-shock epicenter. This aftershock has a depth of $20-25 \mathrm{~km}$. The source functions for the 9 November 1974 earthquake show one simple pulse of moment release with a duration of $10 \mathrm{~s}$. The depth of this large aftershock at the down-dip edge of the aftershock is similar to the depth we obtained for the main shock and suggests that the lower depth extent of the coupled region is only $\sim 25 \mathrm{~km}$.

The large aftershock occurred between the main-shock epicenter and the region of the largest moment release to the southeast (Fig. 8). We cannot determine if this aftershock occurred in a region that had previously failed during the main shock or in a small region left unbroken by the main shock.

\section{The 1966 earthquake}

The 17 October 1966 underthrusting earthquake has a focal mechanism of strike $330^{\circ}$, dip $12^{\circ}$, and rake $90^{\circ}$, and a seismic moment of $20 \times 10^{27} \mathrm{dyn} \mathrm{cm}$, determined by Abe (1972) from surface waves. The relocated aftershocks form three distinct clusters (Dewey and Spence, 1979) (Fig. 1). The largest cluster (referred to as $66 \mathrm{a}$ in Dewey and Spence, 1979), which includes the epicenter, is elongated about $80 \mathrm{~km}$ perpendicular to the trench. Two smaller clusters of aftershocks occur, one cluster (66b) northwest of the epicenter and oceanward of the future 1970 earthquake, and the other cluster $(66 \mathrm{c})$ southeast along strike approximately $80 \mathrm{~km}$. We would like to determine how the main-shock moment release relates to these distinct clusters of aftershocks.

We deconvolved P-wave seismograms to obtain source-time functions using a distributed depth of $10-30 \mathrm{~km}$ (Fig. 9). The lower depth extent is constrained to $30 \mathrm{~km}$, as shown by the increase in the half-absolute moment time $\left(T_{1 / 2}\right)$ (Fig. 10). The source-time functions for the 1966 earthquake consist of one main pulse of moment release but with variable character dependent on the azimuth (Fig. 9). Stations with a northwest, north and northeast azimuth show two to three notches in the source functions, stations to the east and -southeast show one single pulse, and stations to the southwest show a two-pulse source function (Fig. 9). Although we see features in the source functions, we cannot reliably associate the features for directivity analysis.

We used the tomographic imaging inversion method to test for moment release associated with the three clusters of aftershocks. We used a bilateral rupture from -200 to $+200 \mathrm{~km}$, discretized with a $10-\mathrm{km}$ spatial interval, and $120 \mathrm{~s}$ for the source-time functions (Fig. 11). The epicenter is at zero $\mathrm{km}$. Using a rupture direction approximately along strike and rupture velocity of $2.5 \mathrm{~km} \mathrm{~s}^{-1}$, we find moment release near the epicenter and associated with the largest cluster of aftershocks. As shown in Fig. 11, the initial iteration is a symmetric rupture about the epicenter, but subsequent iterations distribute the moment asymmetrically with some weak indication of moment release $80 \mathrm{~km}$ to the southeast. This might correspond to the $66 \mathrm{c}$ aftershock cluster. This is not a robust feature of this data set and should be viewed with caution. We find no indication of any 


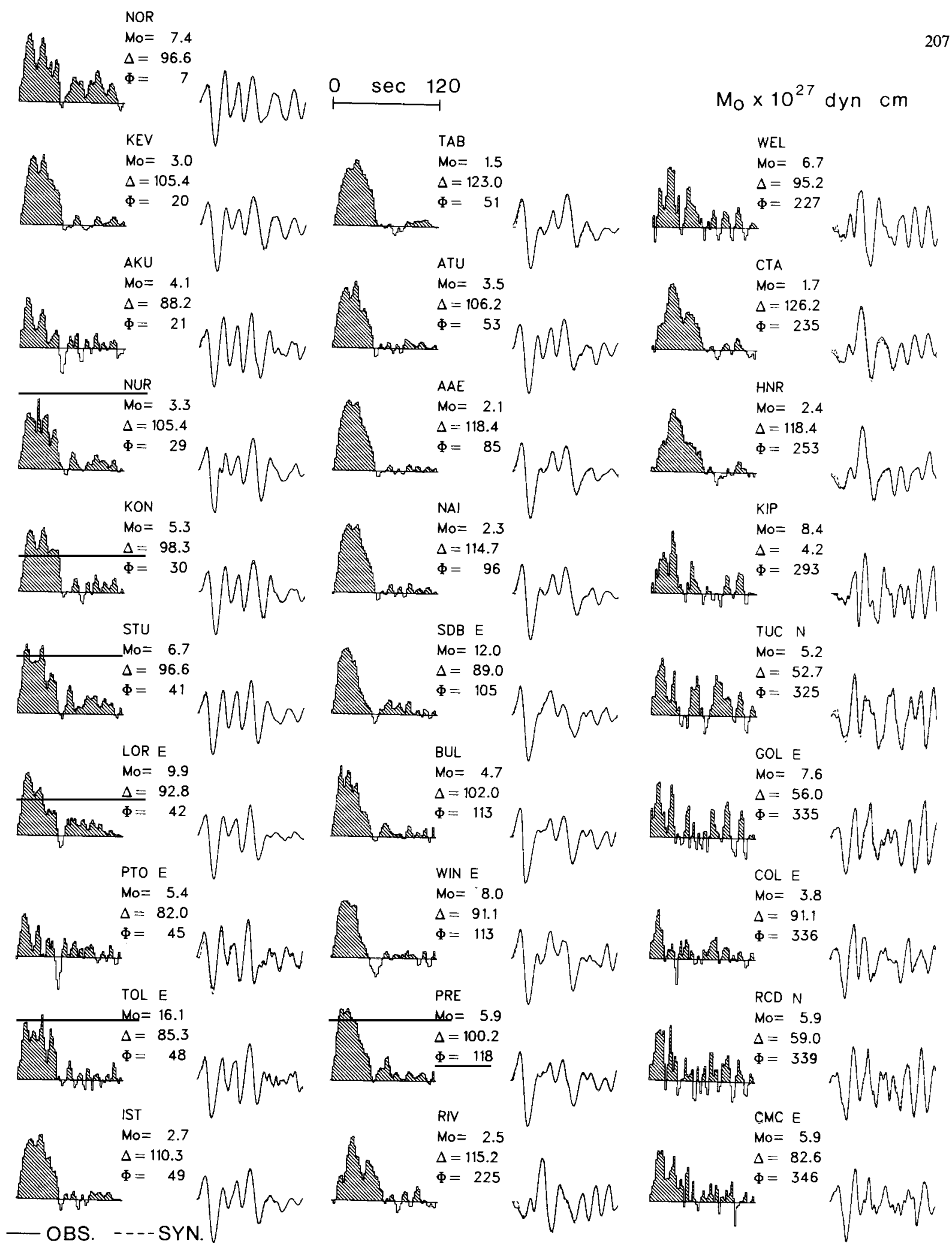

Fig. 9. Source-time functions for the 17 October 1966 earthquake. $\mathrm{N}$ and $\mathrm{E}$ indicate that north-south and east-west components were used rather than vertical components. The solid trace is the observed seismogram and the dashed trace is the synthetic seismogram for the source-time function shown for each station. The P-waves were deconvolved for a distributed depth of 10-30 km. The source functions consist of one major pulse of moment release. 


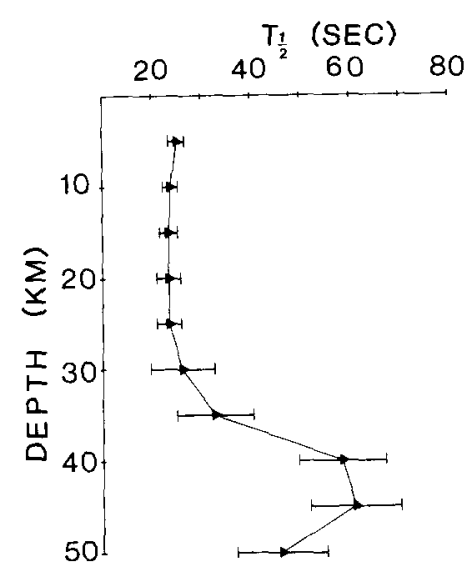

Fig. 10. Plot of the half-absolute moment time $\left(T_{1 / 2}\right)$ versus depth for the 17 October 1966 earthquake. The solid triangles are the average half-moment time from five stations and the error bars are the standard deviation. The half-moment time increases at depths below $35 \mathrm{~km}$ indicating the deepest depth extent of the earthquake.

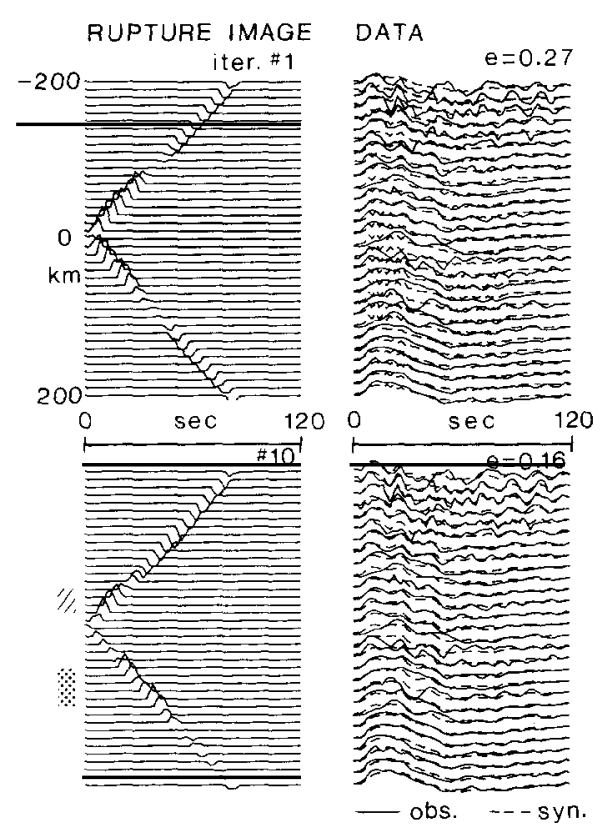

Fig. 11. Plot of the rupture image of the 17 October 1966 earthquake based on the tomographic inversion. The spatial extent is -200 to $+200 \mathrm{~km}$ with a $10-\mathrm{km}$ spacing. The epicenter at $0 \mathrm{~km}$. The rupture azimuth is $N 140^{\circ} \mathrm{E}$ and the rupture velocity is $2.5 \mathrm{~km} \mathrm{~s}^{-1}$. The source-time functions on the right are normalized to a moment of zero. The parameter $e$ decreases from 0.27 to 0.16 from the first to the tenth iteration. moment release to the northwest in the region of the $66 \mathrm{~b}$ aftershock cluster. We conclude that the dominant asperity for the 1966 earthquake was near the epicenter and associated with the largest cluster of aftershocks (Fig. 8). The moment release associated with the $66 \mathrm{c}$ cluster of aftershocks is less clear and may represent a weaker asperity.

There are two intraplate normal-fault earthquakes, on 7 September $1963\left(M_{\mathrm{s}}=6.7\right)$ and 24 September $1963\left(M_{s}=7.0\right)$, that occurred at the down-dip edge of the 1966 main-shock rupture area (Fig. 1). Dewey and Spence (1979) report depths of $64 \mathrm{~km}$ and $75 \mathrm{~km}$ for the two 1963 earthquakes, respectively. Chinn and Isacks (1983) determined a similar depth of $62 \mathrm{~km}$ for the 17 September 1963 event from waveform modeling. These large precursory events may be an indication of the strong coupling of the underthrusting region prior to the 1966 earthquake.

\section{The 1940 earthquake}

There is very little known about the 24 May 1940 , earthquake ( $M=8$, Gutenberg and Richter, 1954) that occurred near the coast of Peru. The lack of a reliable location and focal mechanism has led to uncertainties about whether the event is an interplate or intraplate earthquake. These two possibilities have different tectonic implications. The inland location, deeper depth, and the small number of teleseismically recorded aftershocks suggests that this earthquake may have been within the down-going Nazca plate. This plate boundary is capable of generating very large damaging intraplate events, as is evidenced by the 1970 earthquake. This would imply that the underthrusting region between the 1966 and 1974 earthquakes may be a seismic gap. In contrast, if the 1940 earthquake is an underthrusting event then the entire plate boundary between $10^{\circ}$ and $14^{\circ}$, has failed this century. Dewey (personal communication) has relocated the 1940 earthquake and the largest aftershock relative to the other earthquakes along the Peru trench and obtained a location that is more trenchward than previous locations (Fig. 1). The large aftershock $(M=7)$ occurred the 


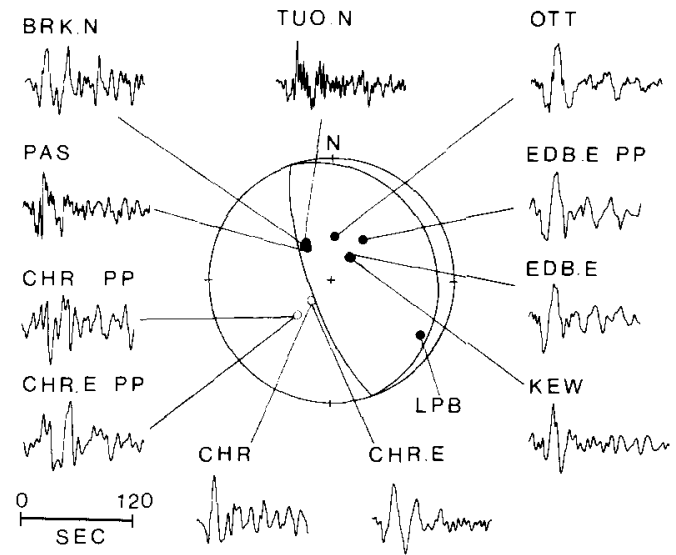

Fig. 12. Lower hemisphere first motion focal mechanism plot for the 24 May 1940 earthquake. The solid circles are compressional first motions and the open circles are dilatational first motions. The P or PP seismograms are plotted starting at the arrival of the earthquake. The steep nodal plane is well constrained and indicates an underthrusting focal mechanism similar to the 1966 and 1974 earthquakes.

same day and is located $60 \mathrm{~km}$ south-southwest of the epicenter (Fig. 1).

Earthquakes that occurred prior to 1963 are more difficult to study owing to the lack of stations and the variations in instruments. We have collected thirteen $\mathbf{P}$ and PP phases from eight stations for the 1940 earthquake and have determined the first motion focal mechanism shown in Figure 12 (Table 2). Stations to the northwest, such as PAS, BRK and TUO, are near nodal but have compressional first motions, OTT, EDB,
KEW, LPB also have compressional first motions, while CHR has a very nodal $P$ phase but a dilatational first motion PP phase (Fig. 12). The steep nodal plane (strike $340^{\circ}$, dip $75^{\circ} \mathrm{SW}$ ) is well constrained. If we assume pure dip-slip then we obtain the same underthrusting focal mechanism as the 1966 and 1974 earthquakes. Thus, we conclude that the 1940 event was an underthrusting earthquake.

Using the underthrusting focal mechanism, we can invert the P and PP phases for source-time functions for the 1940 earthquake. The instrument constants and magnifications are not always reliably known, so we must be cautious with any interpretation. We obtain simple source-time functions with one main pulse of moment release and a total duration of 24-30 s (Fig. 13). The source duration for the 1940 earthquake is about half the source duration of the 1966 and 1974 earthquakes. We determined a lower depth extent of $30 \mathrm{~km}$ using the method described by Christensen and Ruff (1985) (Figure 14).

The seismic moment is not well determined for most stations because of the unreliable magnifications. The most reliable moment estimate is probably $2 \times 10^{27}$ dyn $\mathrm{cm}$ from station KEW because it is not nodal for the direct $\mathrm{P}$-wave and the instrument constants are well documented. Stations such as PAS and TUO have known magnifications and yield much higher moments, but their location near the nodal plane for the direct $P$-wave makes them sensitive to small errors in the focal

TABLE 2

Station parameters for the 1940 earthquake ${ }^{\text {a }}$

\begin{tabular}{|c|c|c|c|c|c|c|}
\hline $\begin{array}{l}\text { Station } \\
\text { abbreviation }\end{array}$ & $\begin{array}{l}\text { Station } \\
\text { location }\end{array}$ & Component & Azimuth $\left({ }^{\circ}\right)$ & $\begin{array}{l}\text { Epicentral } \\
\text { distance }\left({ }^{\circ}\right)\end{array}$ & $T_{\mathrm{s}}(s)$ & $T_{\mathrm{g}}(s)$ \\
\hline$\overline{\mathrm{OTT}}$ & (Ottawa, Canada) & $\mathbf{Z}$ & 1.8 & 56.4 & 1.0 & 75.0 \\
\hline EDB & (Edinburgh, Scotland) & $\mathbf{E}$ & 32.9 & 90.8 & 8.1 & 24.0 \\
\hline KEW & (Kew, Scotland) & $\mathbf{Z}$ & 37.6 & 91.0 & 12.3 & 14.3 \\
\hline CHR & (Christchurch, N.Z.) & $\mathbf{Z}$ & 223.6 & 96.1 & 12.8 & 12.9 \\
\hline CHR & (Christchurch, N.Z.) & $\mathrm{E}$ & 223.6 & 96.1 & 24.4 & 24.4 \\
\hline PAS & (Pasadena, CA, U.S.A.) & $\mathbf{Z}$ & 320.6 & 58.9 & 1.0 & 90.0 \\
\hline BRK & (Berkeley, CA, U.S.A.) & $\mathbf{Z}$ & 322.0 & 64.1 & 12.0 & 12.0 \\
\hline BRK & (Berkeley, CA, U.S.A.) & $\mathbf{N}$ & 322.0 & 64.1 & 12.0 & 12.0 \\
\hline TUO & (Tucson, AZ, U.S.A.) & $\mathbf{N}$ & 324.9 & 53.3 & 10.0 & 10.0 \\
\hline
\end{tabular}

a $\mathrm{Z}$, vertical; $\mathrm{E}$, east-west; $\mathrm{N}$, north-south. Station azimuth in degrees relative to the earthquake. $T_{\mathrm{s}}$ is the seismometer period and $T_{\mathrm{g}}$ is the galvanometer period. 


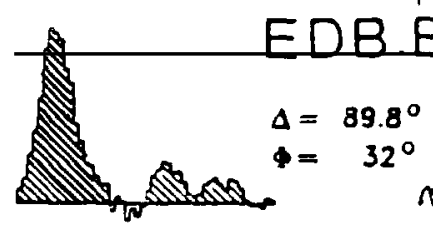

\section{0-30 Km DEPTH}

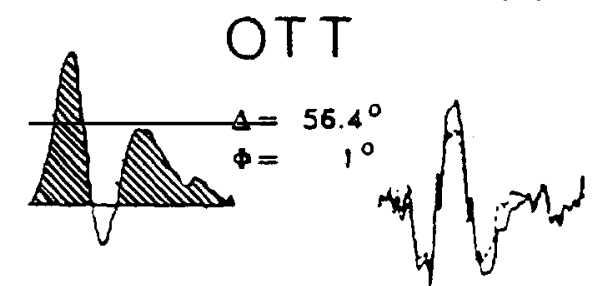

$E$

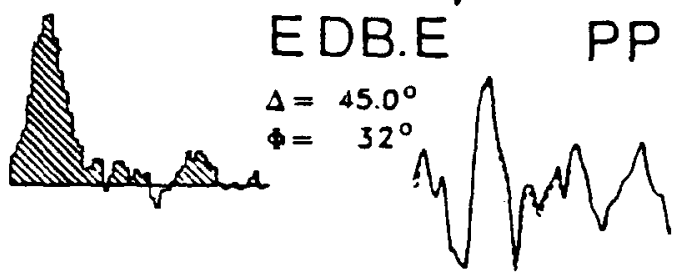

CHR.E

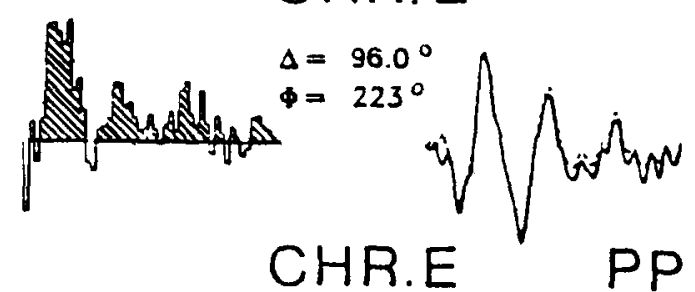

CHR.E
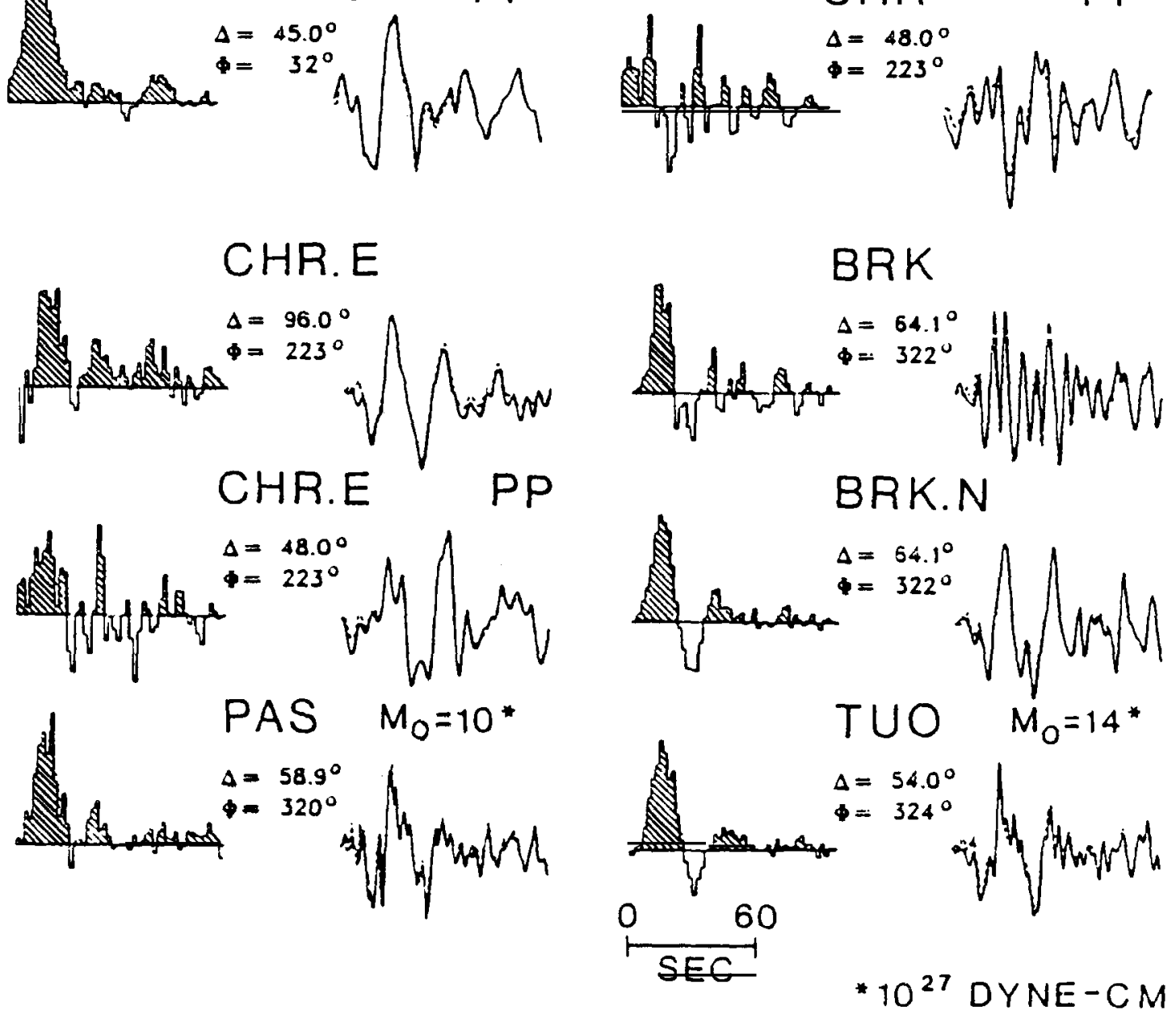

CHR $\quad M_{0}=6$ *

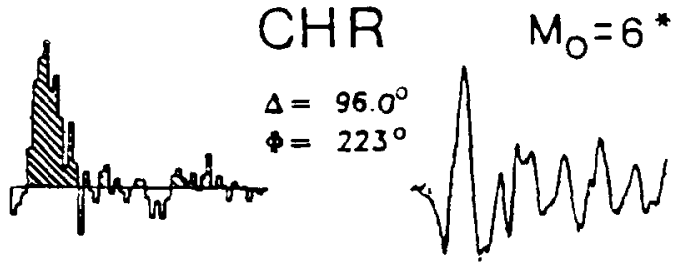

CHR

PP

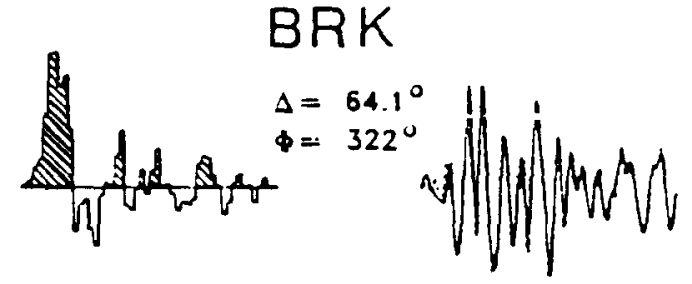

BRK.N

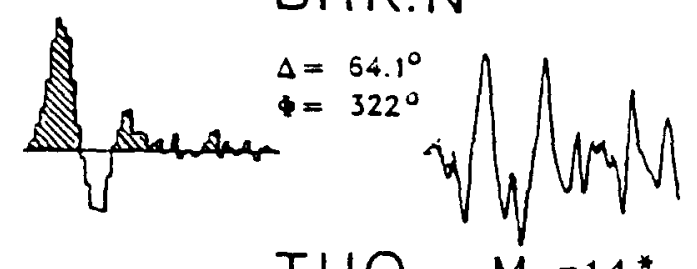

TUO $M_{0}=14^{*}$

Fig. 13. Source-time functions for the 24 May 1940 earthquake. The source-time functions were determined using an underthrusting focal mechanism as shown in Fig. 12 and a distributed depth of 10-30 km. PP indicates a PP phase was used rather than a P phase. 


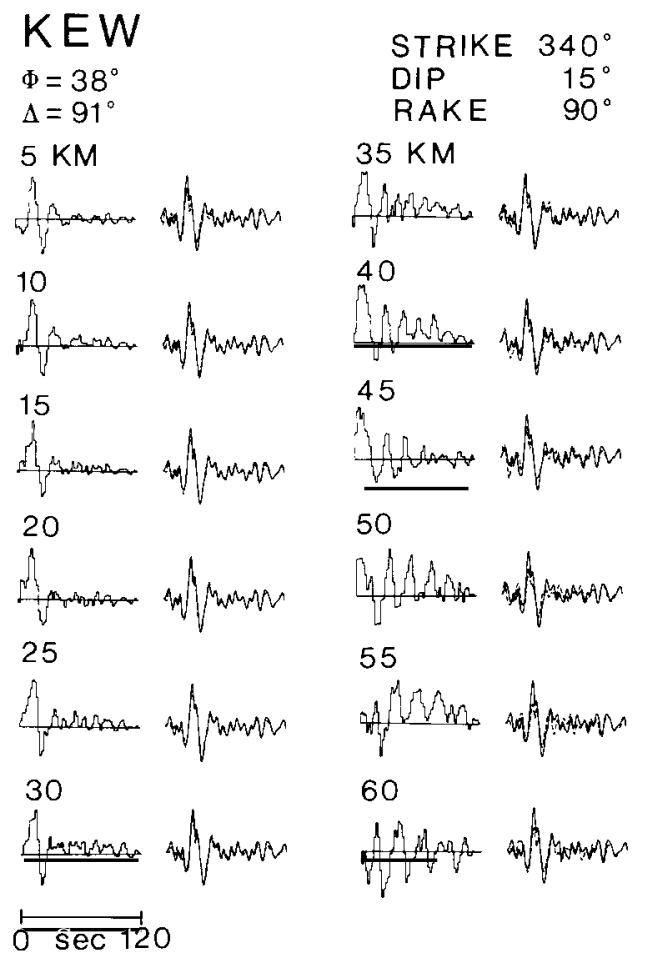

Fig. 14. Plot of source-time functions for the 24 May 1940 earthquake from station KEW deconvolved with a point source at depths from 5 to $60 \mathrm{~km}$. The source functions show the characteristic periodic ringing at depths below $30 \mathrm{~km}$.

mechanism. We cannot spatially locate the moment release with directivity, but given the duration and an average rupture velocity of $2.0 \mathrm{~km} \mathrm{~s}^{-1}$ the majority of moment was probably released within $50 \mathrm{~km}$ of the epicenter. In other subduction zones, such as the Kurile Islands and the Colombia-Ecuador zones, the dominant asperities do not overlap along adjacent segments (Beck and Ruff, 1987; Schwartz and Ruff, 1987). We have suggested that the adjacent 1966 earthquake ruptured to the small aftershock cluster (66c) located near the 1940 epicenter. We can speculate that the dominant asperity for the 1940 earthquake probably does not overlap with the 1966 moment release substantially, and thus occurs to the south-southeast toward the 1974 earthquake.

The large aftershock has a simple source-time function with a duration of 8-10 s, assuming the same focal mechanism as the main shock (Fig. 15).

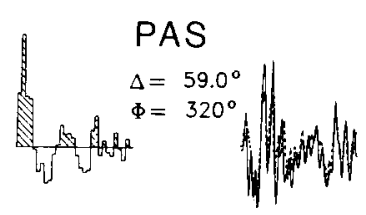

$5 / 24 / 40$
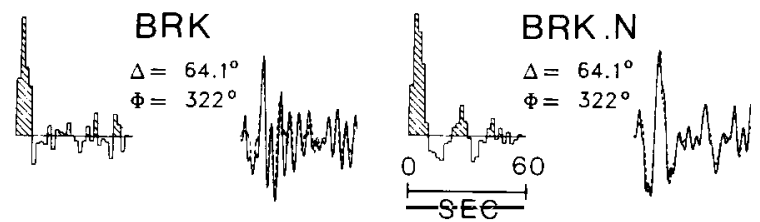

Fig. 15. Source-time functions for the large aftershock on 24 May 1940, for stations PAS and BRK. An underthrusting focal mechanism is used similar to the main shock and a depth of 20 $\mathrm{km}$. The source functions have one simple pulse of moment release with a duration of $10 \mathrm{~s}$.

The depth of the aftershock is $20 \mathrm{~km}$ (Fig. 16). This is consistent with the depth of the main shock.

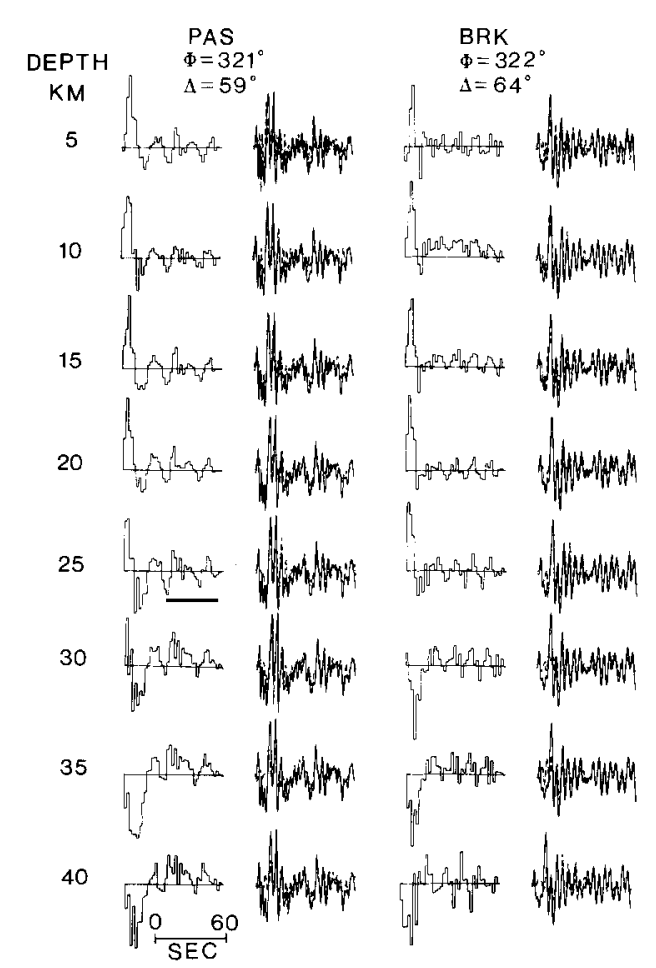

Fig. 16. Source functions for the large aftershock on 24 May 1940 for stations PAS and BRK deconvolved at depths between 5 and $40 \mathrm{~km}$. The best point source depth for this event is $20 \mathrm{~km}$. 


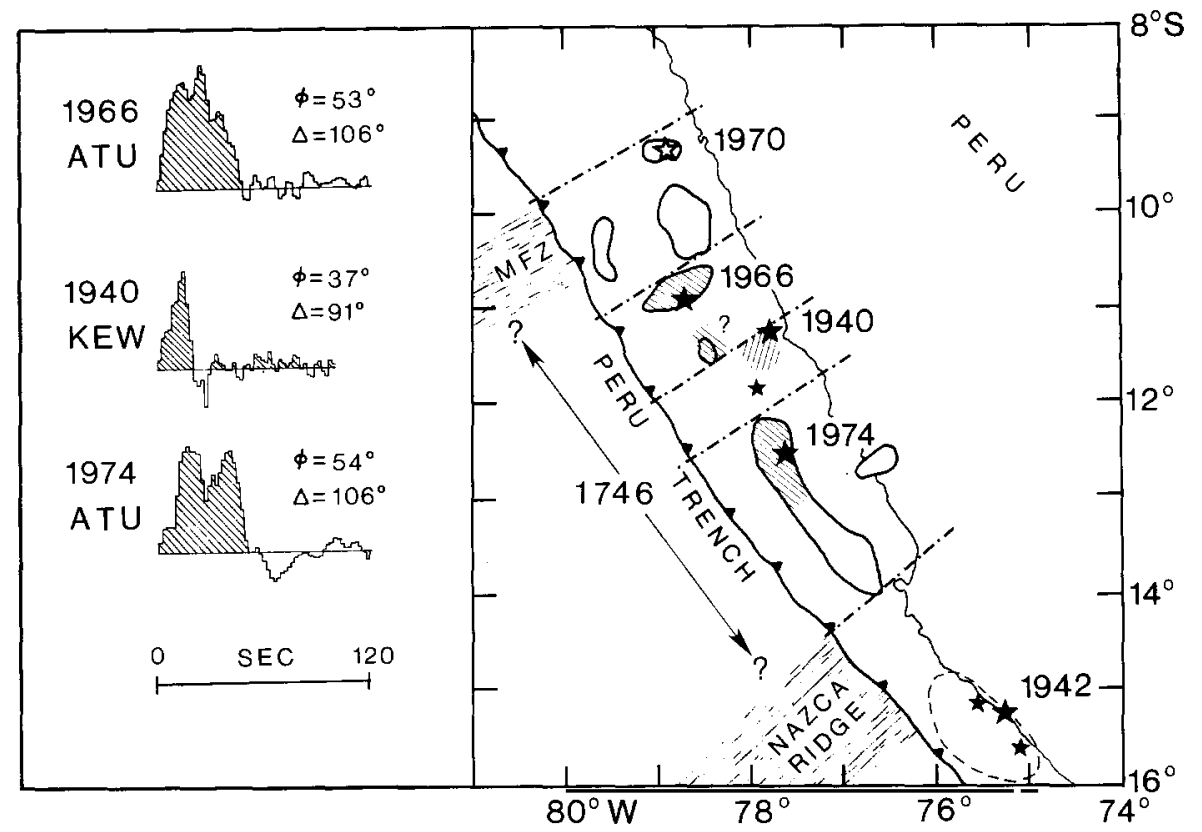

Fig. 17. Summary of the source-time functions and asperity distribution of the three underthrusting earthquakes along the central Peru subduction zone. The hachured regions indicate the dominant asperities.

Thus, the central Peru subduction zone has been ruptured by three underthrusting earthquakes along adjacent segments since 1940. Figure 17 summarizes the temporal and spatial moment release for the three earthquakes. The 1974 earthquake had a bilateral rupture with the moment release concentrated on the northwest half of the fault area. The 1966 earthquake had most of the moment release near the epicenter. There is some weak indication of moment release $\sim 80 \mathrm{~km}$ along strike and southeast of the epicenter. The source duration and seismic moment for the 1940 earthquake are much smaller than that of the 1966 and 1974 earthquakes. The moment release for the 1940 earthquake is concentrated near the epicenter. We conclude that there are three dominant asperities along the central Peru subduction zone.

\section{The 1970 earthquake}

The 31 May 1970, earthquake $\left(M_{\mathrm{w}}=8.0\right)$ was one of the most destructive historic earthquakes in the western hemisphere, causing 70000 deaths and
50000 injuries in west central Peru (Ericksen et al., 1970). The earthquake triggered a debris avalanche that buried the towns of Yungay and Ranrahirca (Ericksen et al., 1970). This was by far the most disastrous earthquake along the Peru coast in terms of loss of life and property. The size was similar to the 1966 and 1974 earthquakes but more damaging probably because of its location farther inland. For this reason it is important to understand the source process and tectonic regime. The historic earthquake record indicates that this type of earthquake has occurred before. Earthquakes on 6 January 1725 and February 1619 , had maximum intensities near $9-10^{\circ} \mathrm{S}$ and caused massive mud and ice debris avalanches similar to the 1970 earthquake (Lomnitz, 1971; Silgado, 1985).

The 1970 earthquake has a normal-fault focal mechanism (strike $340^{\circ}$, dip $53^{\circ}$, rake $-90^{\circ}$ ) determined from surface waves and a seismic moment of $10 \times 10^{27}$ dyn $\mathrm{cm}$ (Abe, 1972). This focal mechanism is consistent with the P-wave first-motion mechanism. Abe (1972) concluded that the 1970 earthquake ruptured the entire thickness of 


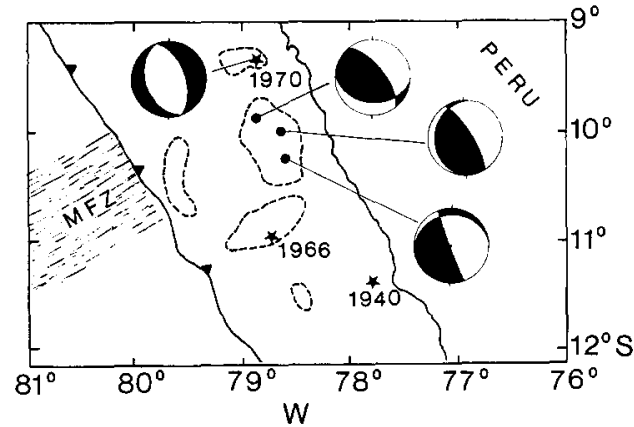

Fig. 18. Map of the 31 May 1970 earthquake aftershock clusters and focal mechanisms of the main shock and three of the largest aftershocks. The main-shock focal mechanism is characterized by down-dip tension. In contrast, the largest cluster of aftershocks are characterized by focal mechanisms with down-dip compression (Isacks and Barazangi, 1977).

the oceanic lithosphere from the stresses due to the sinking slab (Fig. 1).

\subsection{Aftershocks of the 1970 earthquake}

The relocated aftershocks for the 1970 event form two distinct clusters (70a and 70b, Dewey and Spence, 1979) (Fig. 18). The aftershocks in the cluster (70a) near the epicenter have similar focal mechanisms to the main shock characterized by down-dip tension (Stauder, 1975; Isacks and Barazangi, 1977). The second larger cluster of aftershocks (70b) have focal mechanisms characterized by down-dip compression and occur approximately $50-60 \mathrm{~km}$ southeast and along strike from the epicenter (Stauder, 1975; Isacks and Barazangi, 1977; Dewey and Spence, 1979). The first teleseismically recorded aftershock occurred at the south end of cluster $70 \mathrm{~b}$ (Dewey and Spence, 1979). The second cluster of aftershocks occurred over a broad area and their locations are not consistent with occurring on one of the nodal planes defined by the main shock (Dewey and Spence, 1979). The relocations by Dewey and Spence (1979) indicate a depth of $64 \mathrm{~km}$ for the main-shock hypocenter and the first cluster of aftershocks. The second cluster of aftershocks is slightly more shallow with the largest of the aftershocks on 2 June 1970, 4 June 1970 and 4 July 1970 yielding depths of 54,55 and $47 \mathrm{~km}$, respectively. Chin and Isacks (1983) reported simi- lar depths of 59,50 , and $46 \mathrm{~km}$, respectively, for these three aftershocks. If these depths are correct, then the down-dip tensional aftershocks and main shock are slightly deeper than the down-dip compressional aftershocks. Isacks and Barazangi (1977) interpreted this earthquake sequence as the result of unbending stresses. However, the aftershocks in the two clusters do not overlap along strike. We investigate the details of the main-shock rupture to see how it relates to the aftershock clusters and to constrain the tectonic interpretation of this unusual event.

\subsection{P-wave analysis}

We determined source-time functions from 30 P-wave seismograms for the 1970 main shock using the normal-fault focal mechanism determined by Abe (1972) (Figs. 19 and 20). We find 30-40 km to be the deepest depth that produces acceptable source functions (Figs. 21 and 22). Below $40 \mathrm{~km}$ the source functions have periodic ringing indicating depth overestimation (Christensen and Ruff, 1985) (Fig. 21). This is more than $20 \mathrm{~km}$ shallower than the depth determined from the relocations (Dewey and Spence, 1979). A depth of $40 \mathrm{~km}$ is probably very close to the interface between the two plates and suggests that the event did not rupture through the entire thickness of the lithospheric plate as a normal fault (Fig. 1). Figures 19 and 20 show source-time functions for a point source at a depth of $40 \mathrm{~km}$. Source functions at stations such as AFI, KIP and AKU are beginning to show the periodic ringing even at a depth of $40 \mathrm{~km}$.

The source-time functions have one main pulse of moment release followed by a smaller negative pulse (Figs. 19 and 20). The strongest features in the source functions are the truncation of the first pulse and the sharp rise after the negative pulse. These two features correspond to a sharp rise and a sharp fall, respectively, in the seismogram (Figs. 19 and 20). Azimuthal directivity of these two features, as measured from the seismograms and the source functions give locations southeast of the epicenter (Fig. 23). The best overall rupture azimuth is $150-170^{\circ}$ and a distance of 75 and 85 $\mathrm{km}$, respectively, for the two features (Fig. 23). 

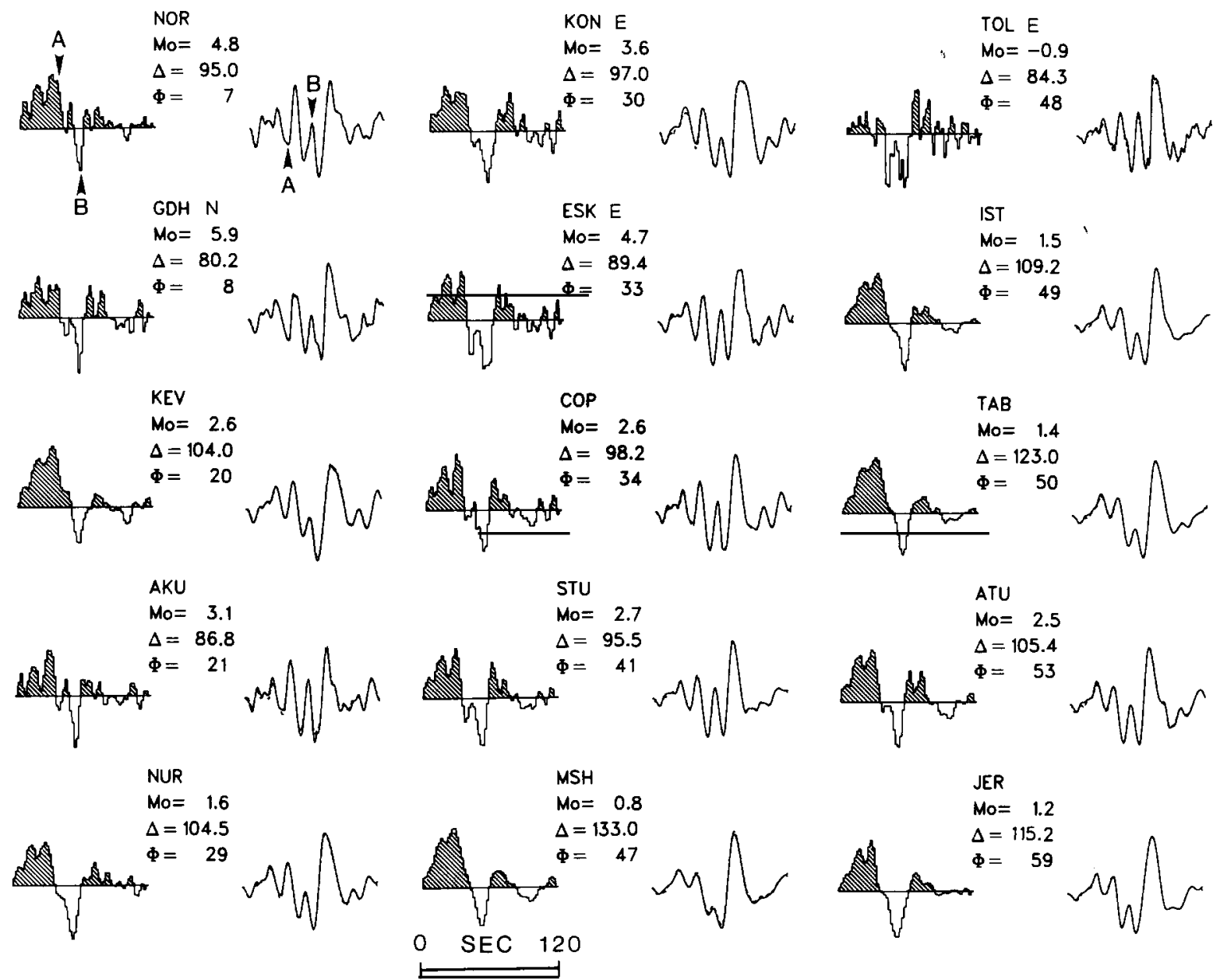

Fig. 19. Source-time functions for the 31 May 1970 earthquake. A normal-fault focal mechanism (strike $340^{\circ}$, dip $53^{\circ}$ and rake $-90^{\circ}$ ) is used and a point source at $40 \mathrm{~km}$ depth. The seismic moment for the non-diffracted stations is in units of $10^{27} \mathrm{dyn} \mathrm{cm}$.

The first pulse of moment release occurred between the epicenter and $75 \mathrm{~km}$ to the southeast within the second cluster of aftershocks. This result indicates that the main-shock rupture extent overlaps with the cluster of aftershocks with down-dip compression. The strong rise (and associated negative pulse of moment release) in the source functions is more difficult to interpret. The strong rise is a consistent feature at all stations but RIV and WEL. This feature also has azimuthal directivity that gives a location $85 \mathrm{~km}$ southeast of the epicenter and corresponds to the location of the second cluster of aftershocks. This is the same location as the truncation of the first pulse of moment release.

We could adjust the baseline of the source-time functions and add a long-period component of moment release to make the source functions mostly positive and still fit the observed seismograms. This would give us two large pulses of moment release and a seismic moment three to four times larger than the surface-wave moment. The average $\mathrm{P}$-wave seismic moment should not be larger than the surface-wave estimate. Hence, increasing the seismic moment by a factor of three to four is not a likely interpretation. 


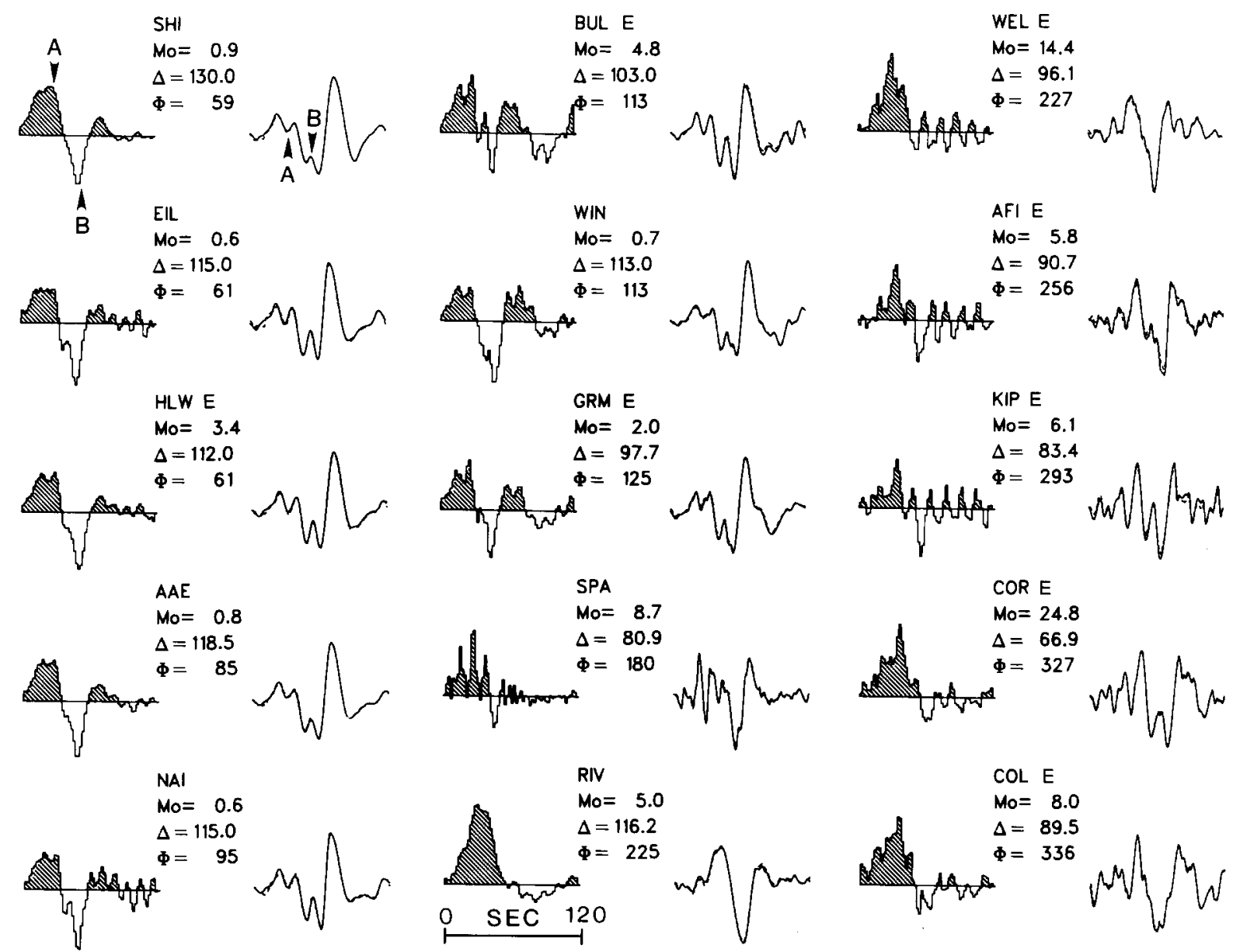

Fig. 20. Same as Fig. 19.

The other alternative is that the strong negative pulse indicates an incorrect Green's function, that is an incorrect depth, focal mechanism, or both. We have tested for the best depth and found that the negative pulse is not a result of an incorrect depth. We must therefore reassess the focal mechanism.

\subsection{Dual focal mechanism}

It seems reasonable to assume that the aftershock complexity reflects the main shock complexity. That is, the main shock was a double event with two different focal mechanisms and depths. We inverted the source functions assuming a depth of $50 \mathrm{~km}$ and a normal-fault focal mecha- nism for the first $40 \mathrm{~s}$ and a depth of $30 \mathrm{~km}$ and a reverse fault focal mechanism (strike $340^{\circ}$, dip $50^{\circ}$ and rake $90^{\circ}$, i.e., down-dip compression as indicated by the aftershocks) after $40 \mathrm{~s}$ (Figs. 24 and 25). The change in focal mechanism flips the polarity of the negative pulse to a positive pulse in the source-time function. The second source is about one-third to one-quarter the size of the first source. The second source is constrained to be less than $30-40 \mathrm{~km}$, otherwise we obtain the characteristic periodic ringing. The first source is not as well-constrained, but the fit to the initial part of the waveform decreases for depths below 50-60 $\mathrm{km}$. The average seismic moment determined from the undiffracted P-waves is $16 \times 10^{27} \mathrm{dyn} \mathrm{cm}$. Figure 26 shows a summary of the dual focal 
216

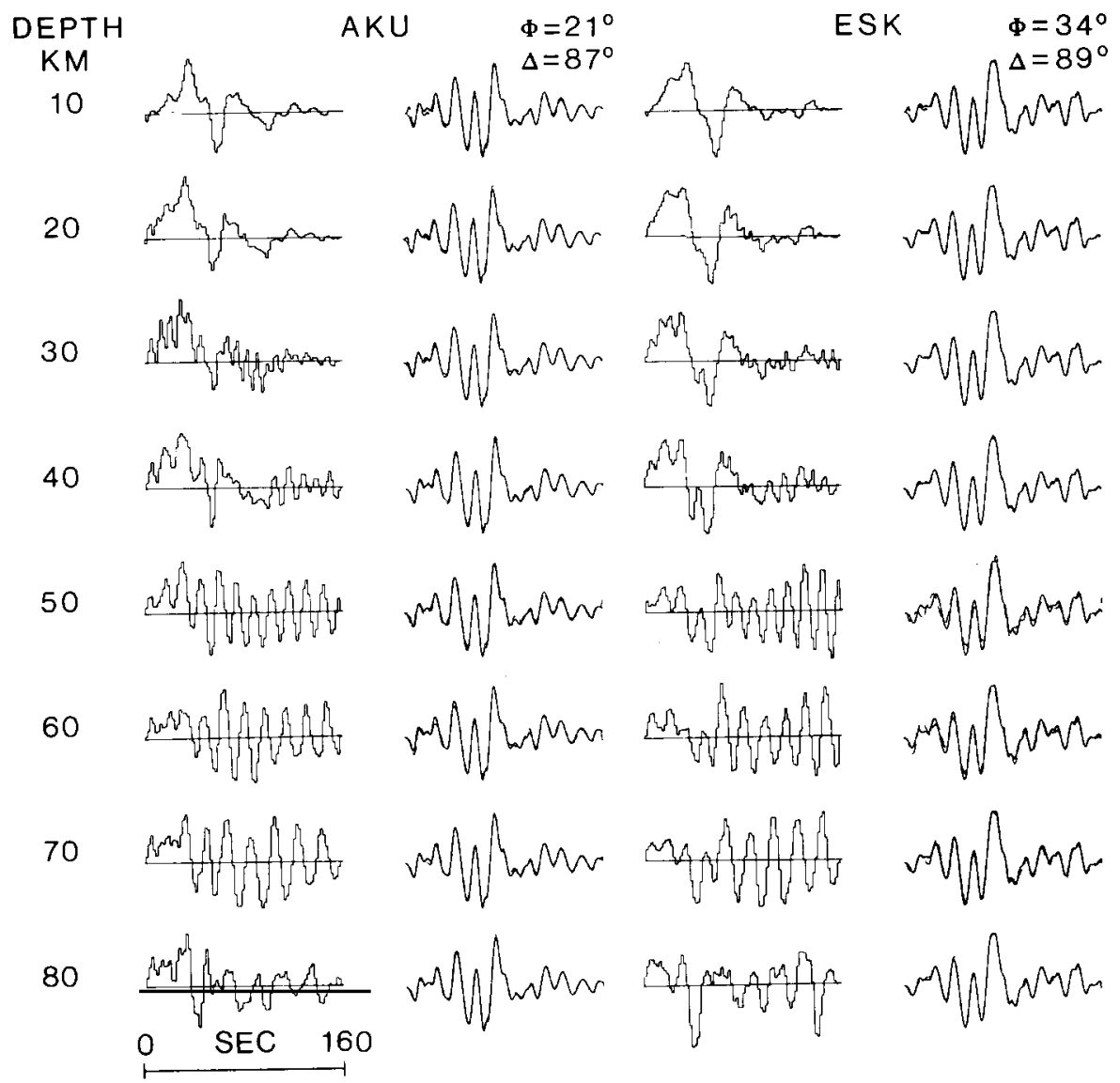

Fig. 21. Source-time functions for the 31 May 1970 earthquake at depths between 10 and $80 \mathrm{~km}$ for stations AKU and ESK. The source functions show periodic ringing at depths below $40 \mathrm{~km}$.

mechanism source model of the 1970 earthquake. This model yields remarkably consistent source functions at all stations except RIV, which did not have the negative pulse (Figs. 24 and 25).

We tested the possibility that the second focal mechanism might be an underthrusting mechanism. For most stations we could not distinguish between an underthrusting and high-angle reverse fault. But for stations such as AFI and KIP, the underthrusting focal mechanism does not change the polarity and flip the pulse.

We also investigated the effect of the dual focal mechanism model on the surface waves for the 1970 earthquake. A source with a normal-fault focal mechanism followed $40 \mathrm{~s}$ later by a source with a reverse-fault focal mechanism at longer periods would cancel and hence, decrease the spectral amplitude. We looked at the spectral amplitudes of $\mathrm{R} 3$ and $\mathrm{G} 3$ recorded at stations $\mathrm{COP}$ and STU and found the results to be inconclusive. We calculated synthetic R3 and G3 surface waves for the two models, a single normal-fault focal mechanism and the dual focal mechanism model assuming the second source was one-third the size of the first source and delayed $40 \mathrm{~s}$. A comparison of the spectral amplitudes for the two models showed the expected decrease in spectral amplitude for the dual focal mechanism model but by such a small amount that it would be hard to resolve with real data. We conclude that the size of the second source with the reverse focal mechanism and the time delay are not large enough to be identified by the surface waves. If the dual focal mechanism model is correct then the surface- 


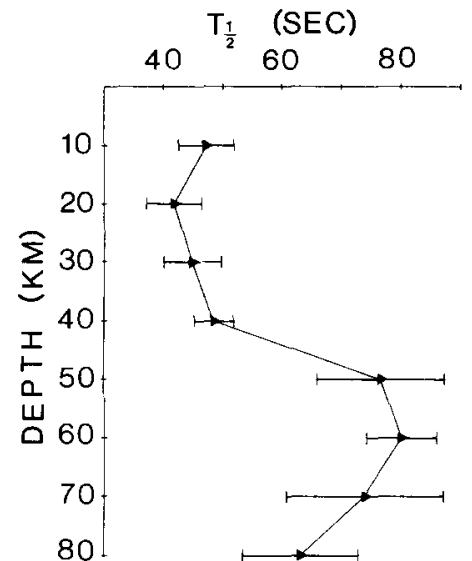

Fig. 22. Plot of the half-absolute moment time $\left(T_{1 / 2}\right)$ versus depth for the 31 May 1970 earthquake. The triangles are the average for six stations with the bars showing the standard deviation. The half-moment time increases at depths below 40 $\mathrm{km}$ indicating the lower depth extent of the earthquake.

wave seismic moment determined from amplitudes by Abe (1972) would underestimate the true seismic moment for the 1970 earthquake.

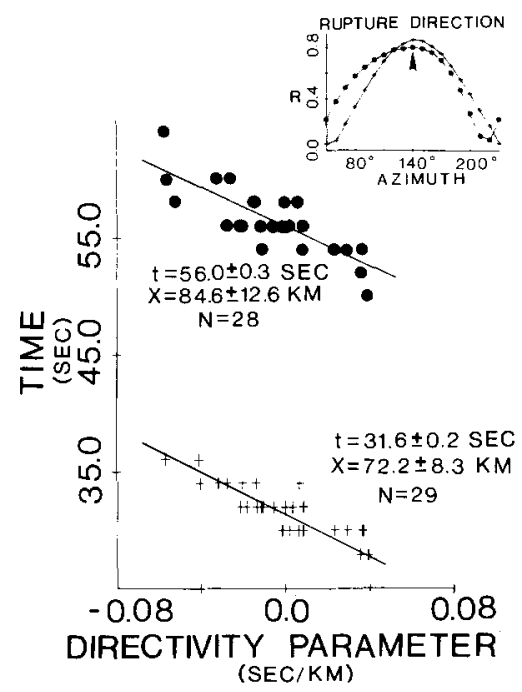

Fig. 23. Best fit (least squares) straight line for the delay time $\left(T_{i}\right)$ versus the directivity parameter $\left(\Gamma_{i}\right)$ for the two features on the source-time functions (A and B) for the 31 May 1970 earthquake. The best rupture direction is $140^{\circ}$ for each feature as shown by the plot of the correlation coefficients $(R)$ for the best fit straight line versus rupture azimuth. Both features are located $70-85 \mathrm{~km}$ southeast of the epicenter.
Our two focal mechanism model for the main shock is consistent with the observed P-waves, though it certainly is not unique. The second focal mechanism is poorly constrained, though we can eliminate an underthrusting mechanism. Our proposed model for the 1970 main shock, as motivated by the occurrence of the two aftershock clusters, is consistent with the unbending hypothesis of Isacks and Barazangi (1977). We observe down-dip compression slightly shallower than down-dip tension. If this complicated multiple event is the result of unbending, then the 1970 earthquake is the largest dual-mechanism 'unbending' event identified.

\section{Discussion and conclusions}

\subsection{Historic seismicity}

The central Peru subduction zone has a long history of destructive earthquakes. We have surveyed the historic earthquake record for the coast of central Peru to determine when and where previous large earthquakes have occurred and how they might compare with the earthquakes that have occurred this century. Most of the historic data consists of descriptions of damage and tsunami heights. The historic earthquake and tsunami record for Peru has been compiled in two publications (Lockridge, 1985; Silgado, 1985), which we have used extensively. In many cases we could not go back to the original source. For comparison, the 1966 and 1974 underthrusting earthquakes produced local tsunami heights (maximum double amplitudes) of 3.5 and $2 \mathrm{~m}$, and teleseismic tsunami heights along the coast of Japan of $15-20$ and $20 \mathrm{~cm}$, respectively (Hatori, 1981). Lockridge (1985) reports a local tsunami height of $2 \mathrm{~m}$ for the 1940 earthquake with a questionable validity number and we can find no mention of it in any other source.

An earthquake occurred on 30 March 1828 , at $12^{\circ} \mathrm{S}$, with a reported maximum intensity of VIII (Lomnitz and Cabre, 1968; Silgado, 1985). There is no report of a tsunami for this earthquake and there is no mention of this earthquake by Lockridge (1985), Berninghausen (1962) or Heck (1947). 


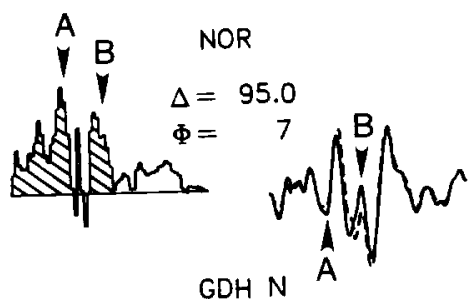

GDH N

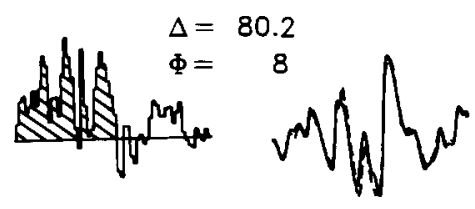

KEV

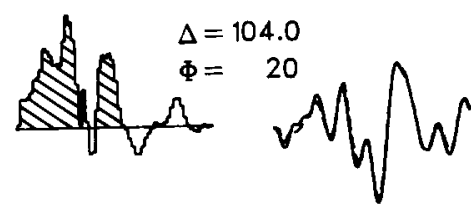

AKU

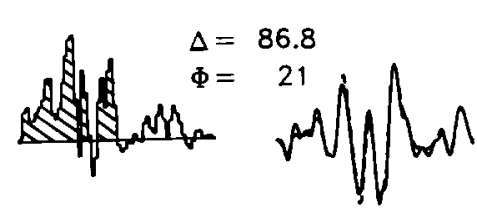

NUR

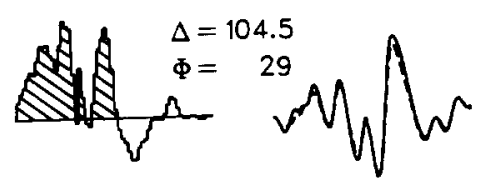

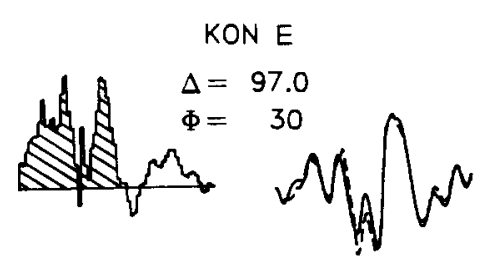

ESK E

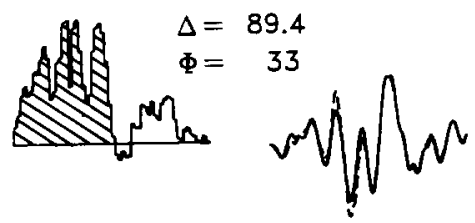

COP

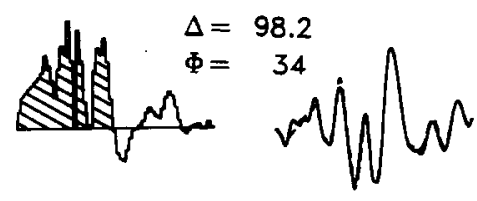

STU

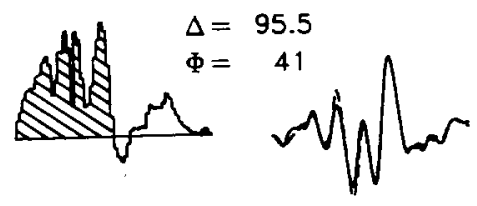

MSH

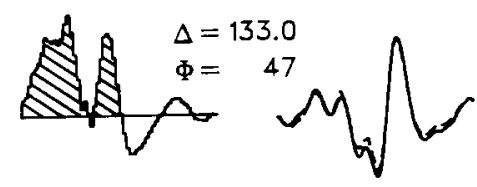

TOL E

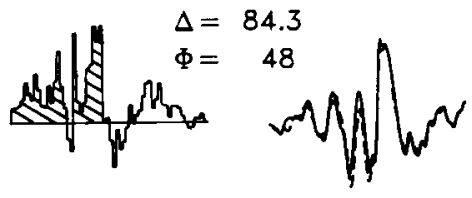

IST

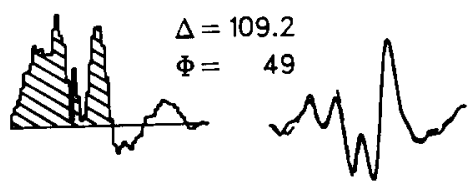

TAB

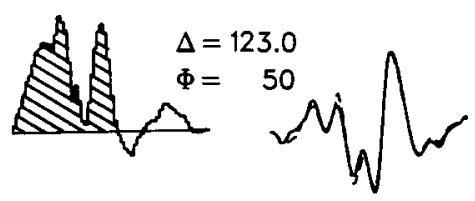

ATU

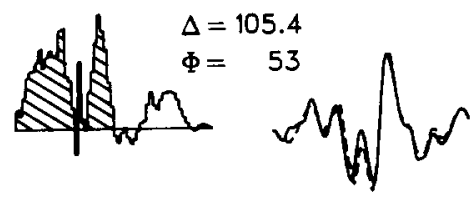

JER

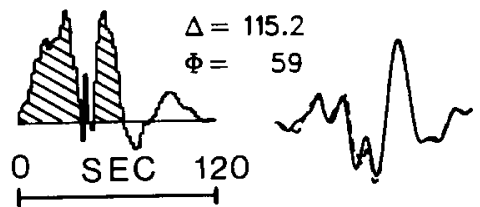

Fig. 24. Source-time functions for the 31 May 1970 earthquake using two focal mechanisms. The first $40 \mathrm{~s}$ are deconvolved with a normal-fault focal mechanism (strike $340^{\circ}$, dip $53^{\circ}$ and rake $-90^{\circ}$ ) and a depth of $50 \mathrm{~km}$. After $40 \mathrm{~s}$ the P-waves are deconvolved with a reverse-fault focal mechanism (strike $340^{\circ}$, dip $50^{\circ}$ and rake $90^{\circ}$ ) and a depth of $30 \mathrm{~km}$. The average moment for the non-diffracted stations is $16 \times 10^{27} \mathrm{dyn} \mathrm{cm}$.

The next previous earthquake occurred on 28 October 1746 , with a maximum reported intensity of $\mathrm{X}$ at $11-12^{\circ} \mathrm{S}$ (Silgado, 1985). The 1746 earthquake had a very large local tsunami height of 24-25 $\mathrm{m}$ with the city of Callao totally destroyed and nearly 5000 deaths (Heck, 1947; Berninghausen, 1962; Lockridge, 1985; Silgado, 1985). However, there is no report of a tsunami in Japan associated with the 1746 earthquake by Hatori (1968) or Watanabe (1968). Lockridge (1985) re- ports a tsunami in Mexico for the 1746 event. The 1746 earthquake appears much larger than any one of the earthquakes along the Peru coast this century. The 1746 earthquake may have ruptured more than one and possibly all three of most recent earthquake zones. Destructive earthquakes also occurred on 20 October 1687 and 9 July 1586 along the Peru coast, with maximum intensities reported of XI at $13^{\circ} \mathrm{S}$ and IX at $12^{\circ} \mathrm{S}$, respectively (Silgado, 1985). Both these earthquakes pro- 


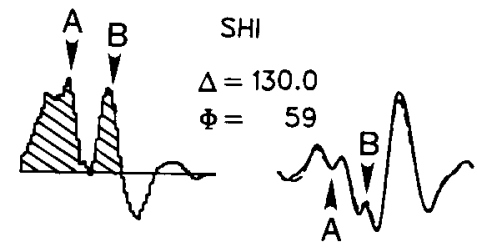

EIL

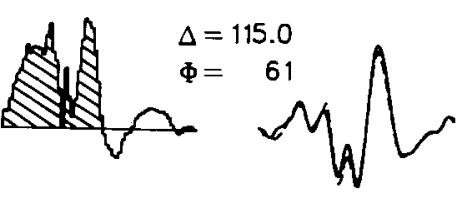

HLW E

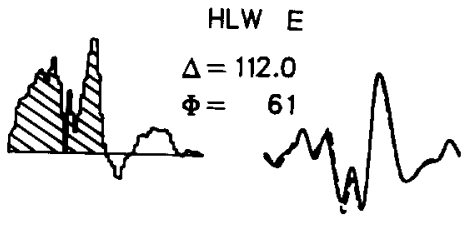

AAE
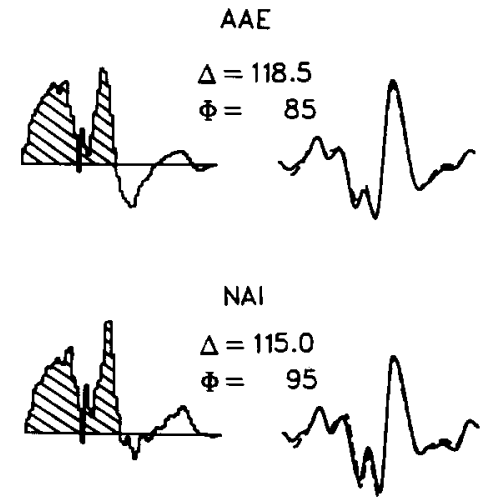

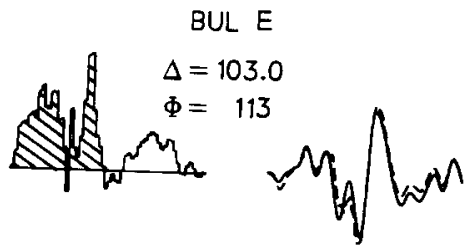

WIN

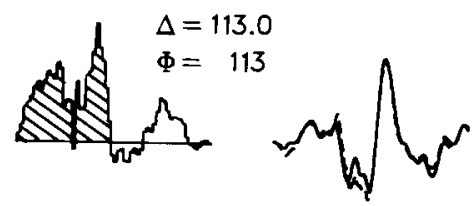

GRM E

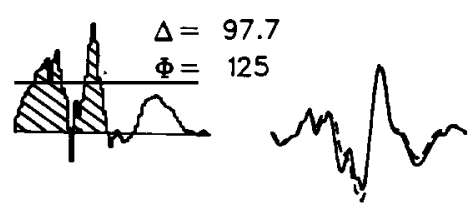

SPA

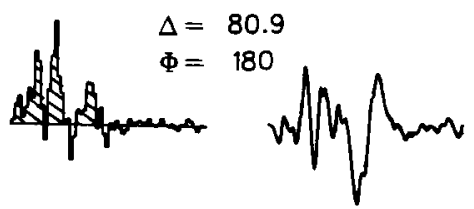

RIV

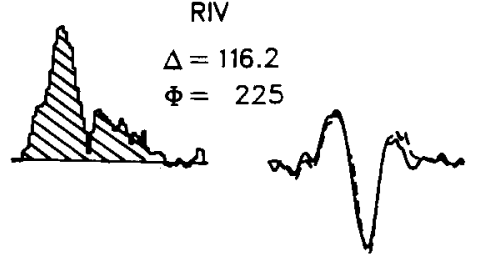

WEL E

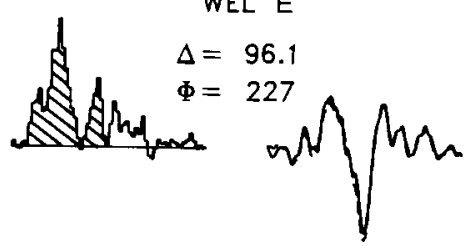

AFI E

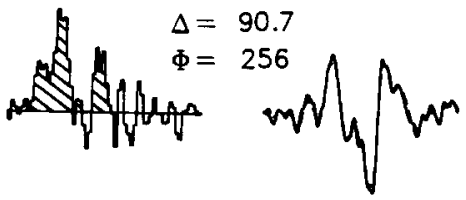

KIP $E$
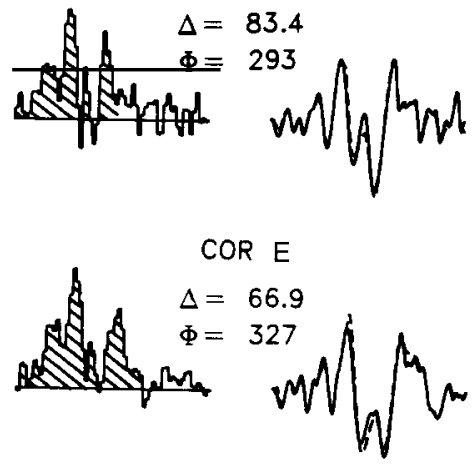

COL E

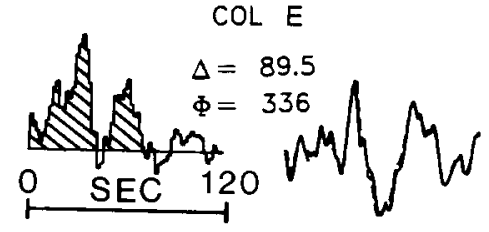

Fig. 25. Same as Fig. 24.

duced very large local tsunami heights of 8 and 24 $\mathrm{m}$, respectively (Berninghausen, 1962; Lockridge, 1985). Hatori (1968, figure 1) indicates far-field tsunami heights of 1 and $2 \mathrm{~m}$ along the Japan coast for the 1687 and 1586 earthquakes. Watanabe (1968) reports tsunamis were observed along the Sanriku coast for the 1586 event and that the tsunami height for the 1687 event was $50 \mathrm{~cm}$ near Sendai. For comparison the great 1906 earthquake $\left(M_{\mathrm{w}}=8.8\right.$ ) along the Colombia-Ecuador coast produced tsunami heights of $30-40 \mathrm{~cm}$ along the coast of Japan (Hatori, 1968). It is hard to effectively evaluate the size of historic earthquakes based on tsunami and damage reports, but the literature suggests that the 1746, 1687 and 1586 earthquakes may have been much larger than any of the three underthrusting events (1940, 1966 and 1974) this century. It may be fairly common for truly great earthquakes to rupture the segment from 10 to $14^{\circ} \mathrm{S}$ along the Peru trench. Thus, the mode of rupture along the Peru coast has changed between successive earthquake cycles.

The maximum displacement we can resolve for the 3 October 1974, Peru earthquake is $7 \mathrm{~m}$. If this segment of the plate boundary failed previously in 1828 , then we might expect $12 \mathrm{~m}$ of accumulated 

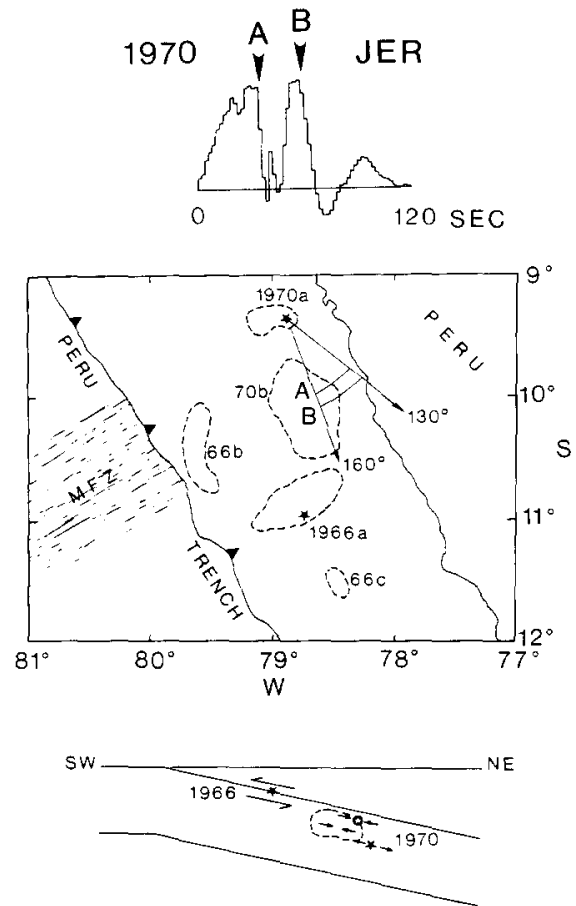

Fig. 26. Map of the directivity results for the 31 May 1970 earthquake. Features A and B occur at the same location $70-85 \mathrm{~km}$ southeast of the epicenter and in the center of the large cluster of aftershocks.

tectonic displacement. However, it is not clear if the 1828 event failed the 1974 segment or the adjacent segment to the north. If the next previous event was in 1746, then the accumulated tectonic displacement would be nearly $20 \mathrm{~m}$. For either case, the maximum fault displacement we can resolve for the 1974 earthquake is less than the accumulated tectonic displacement. We do not have reliable estimates of the maximum displacement for the 1966 and 1940 Peru earthquakes, however, it seems likely that the displacements would also be less than the accumulated tectonic displacement.

The age of the subducting plate and the convergence rate are correlated with the seismic coupling and hence, the maximum size earthquake (Ruff and Kanamori, 1980). The age of the subducting sea floor along the Peru coast is $45 \mathrm{Ma}$ and the convergence rate is $9 \mathrm{~cm} \mathrm{a}^{-1}$. These parameters indicate relatively strong coupling. In fact, the parameters are very similar to the Colombia-
Ecuador subduction zone where the maximum size earthquake is $M_{\mathrm{w}}=8.8$ (1906). In contrast, the maximum size event along the Peru coast this century is only 8.1 , yet the predicted magnitude from the plate age and convergence rate is 8.8 (Ruff and Kanamori, 1980). This discrepancy may actually be due to our limited view of the seismic record. The maximum size earthquake along the Peru trench may be much larger than the earthquakes that have occurred this century.

\subsection{Lateral segmentation along the Peru trench}

The first-order features that define the lateral segmentation on the Nazca plate are the Mendaña fracture zone between 9 and $10^{\circ} \mathrm{S}$ and the Nazca Ridge between 14 and $15^{\circ} \mathrm{S}$. The underthrusting earthquakes do not rupture across these two features, hence they act to permanently segment the subduction zone. We would like to relate the segmentation of large underthrusting earthquake rupture zones with observable structures on the down-going plate or in the trench.

Aseismic features such as the Nazca ridge are generally thought to decrease the seismic coupling between plates (Kelleher and McCann, 1976). Indeed we find no evidence of a large earthquake occurring between 14 and $15.5^{\circ} \mathrm{S}$, where the highest part of the Nazca ridge intersects the trench. The Nazca ridge is a broad feature as it intersects the trench and causes morphotectonic changes at $12^{\circ} \mathrm{S}$ (Schweller et al., 1981). Schweller et al. (1981) report changes in trench depth, axial sediment thickness, and oceanic plate fault structures near $12^{\circ} \mathrm{S}$, which is the northern termination of the 1974 zone. The trench depth is $6.5 \mathrm{~km}$ near the 1966 and 1940 earthquakes, but at $12^{\circ} \mathrm{S}$ begins to shallow as a result of the Nazca ridge (Schweller et al., 1981). The trench depth decreases $\sim 2 \mathrm{~km}$ between 12 and $15^{\circ} \mathrm{S}$. There is no sediment in the trench between 12 and $14^{\circ} \mathrm{S}$. The strike of the fabric or normal faults on the downgoing Nazca plate change orientation from $\mathrm{N} 30^{\circ} \mathrm{W}$ north of $12^{\circ} \mathrm{S}$ to $\mathrm{N} 15^{\circ} \mathrm{W}$ south of $12^{\circ} \mathrm{S}$. The 1974 earthquake occurred on the northwest flank of the Nazca ridge. The dominant asperity for the 1974 earthquake occurred on the northwest half of the aftershock area away from the Nazca 
ridge. The moment release for the 1974 earthquake was not truncated suddenly by the ridge but rather the moment release decreases toward the ridge.

The Mendaña fracture zone is a major fracture zone consisting of northeast-trending ridges and troughs with up to $1 \mathrm{~km}$ of relief (Warsi et al., 1983). The Mendaña fracture zone widens from 50 $\mathrm{km}$ at $84^{\circ} \mathrm{W}$ to $100 \mathrm{~km}$ when it intersects the trench (Warsi et al., 1983). The spacing of the individual ridges diverges $8-10^{\circ}$ as the Mendaña fracture zone approaches the trench. Warsi et al. (1983) suggests that the Mendaña fracture zone is an active feature along which rifting may be occurring. The complex 1970 earthquake occurs where the Mendaña fracture zone enters the trench.

The Mendaña fracture zone and the 1970 event form the boundary between subduction zones with very different behavior. The location on this boundary may be important for the occurrence of the 1970 earthquake. The region to the south has a history of underthrusting earthquakes. In contrast, the region to the north has no known record of large to great underthrusting earthquakes. The historic record extends back at least 500 years for most of South America. There are two end-member possibilities for the state of seismic coupling in this region between the Carnegie Ridge and the Mendaña fracture zone. (1) The plate boundary is strongly coupled with repeat times of greater than 500 years. In this case the plate boundary would be accumulating $8-9 \mathrm{~cm} \mathrm{a}^{-1}$ of convergence over the last 500 years. (2) The plate boundary is uncoupled and aseismically slipping with no potential for great earthquakes.

An important unanswered question is whether the underthrusting region trenchward of the complex 1970 earthquake, where the Mendaña fracture zone enters the trench, is capable of a large underthrusting earthquake. We found no indication of moment release for the 1966 earthquake trenchward of the 1970 earthquake. The 1966 aftershock cluster that is near the trench in front of the 1970 event (cluster 66b, Fig. 1) could be in the outer rise. There was an earthquake in 1967 $\left(M_{\mathrm{s}}=6.7\right)$ in the same location as the $66 \mathrm{~b}$ aftershock cluster with an oblique reverse-fault focal mechanism indicating down-dip compression
(Fig. 1) (Dewey and Spence, 1979). As interpreted by Christensen and Ruff (1988) the 1967 earthquake indicates that the outer rise is in compression due to a locked underthrusting zone. The occurrence of the 1966 earthquake would have helped laterally load the adjacent outer rise. In this case, the underthrusting region trenchward of the 1970 earthquake is still locked and an underthrusting event is likely. In contrast, the region may be weakly coupled and not capable of generating a large underthrusting event. The weak coupling might be due to the subduction of the Mendaña fracture zone. The fracture zone may break up the contact between the plates and prevent a large earthquake. If the fracture zone is actively spreading then this might also influence the seismic coupling of the plates. The role of the subducting Mendaña fracture zone is not understood but is probably important in the occurrence of earthquakes along this segment of the Peru trench.

\subsection{Variations in asperity distribution}

In this section, we briefly compare the asperity distribution of the central Peru subduction zone with two other well-studied subduction zones, the Kurile Islands and Colombia-Ecuador zones. Figure 27 shows a schematic summary of space-time earthquake occurrence and the asperity distribution along strike for the three subduction zones. Four great earthquakes occurred this century along adjacent segments of the Kurile Islands subduction zone. They are from southwest to northeast: $1973\left(M_{\mathrm{w}}=7.8\right), 1969\left(M_{\mathrm{w}}=8.1\right), 1958(M=8.3)$ and $1963\left(M_{\mathrm{w}}=8.5\right)$. The 1973, 1969 and 1958 earthquakes resulted in the failure of one dominant epicentral asperity (Schwartz and Ruff, 1987). In contrast, the largest event in 1963 resulted in the failure of three dominant asperities (Beck and Ruff, 1987). The 1963 earthquake is one of the best-studied examples of a great multiple asperity rupture.

The Colombia-Ecuador subduction zone is probably the best example of different modes of earthquake rupture (Kanamori and McNally, 1982). A great earthquake $\left(M_{\mathrm{w}}=8.8\right)$ occurred in 1906 along the Colombia-Ecuador coast with an 

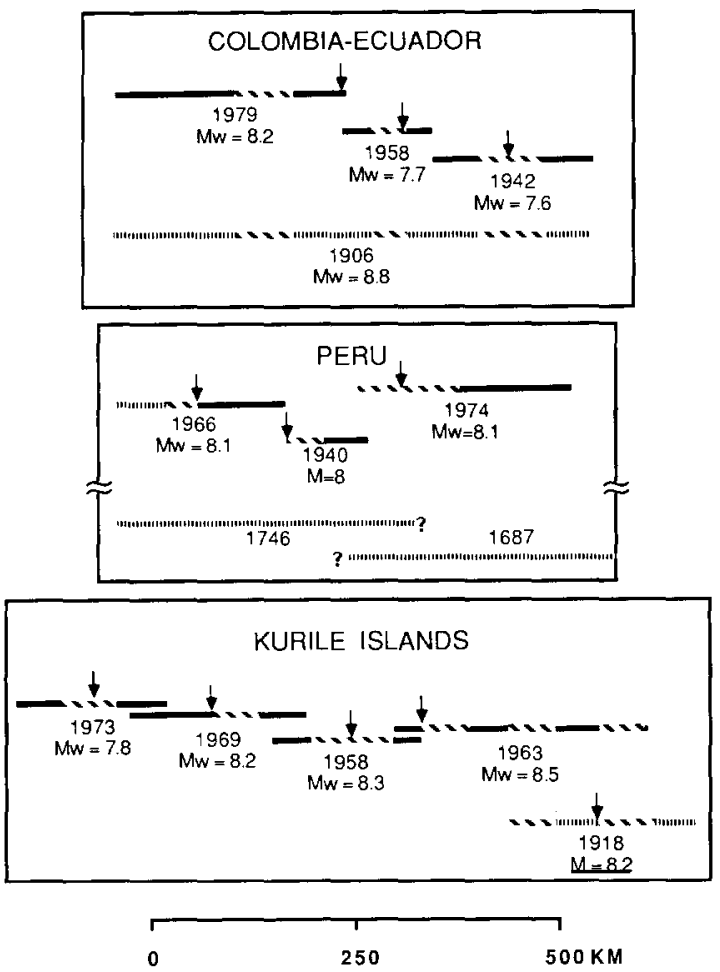

Fig. 27. Summary of the asperity distribution for two successive earthquake cycles along the Kurile Islands, ColombiaEcuador and Central Peru subduction zones plotted as schematic space-time histories. The main-shock epicenters are the stars, except for the 1906 and 1746 earthquakes where the epicenters are unknown. The hachured regions represent the dominant asperities along each fault zone.

estimated rupture length of $500 \mathrm{~km}$ (Kelleher, 1972; Kanamori and McNally, 1982). This same segment subsequently ruptured in three smaller underthrusting events from south to north in 1942 $\left(M_{\mathrm{w}}=7.6\right), 1958\left(M_{\mathrm{w}}=7.7\right)$ and $1979\left(M_{\mathrm{w}}=8.2\right)$ (Kanamori and McNally, 1982). The fault areas, as defined by the aftershocks for these events, abut each other but do not overlap along strike (Mendoza and Dewey, 1984). These three earthquakes each failed with one dominant asperity. The dominant asperities for the 1958 and 1942 earthquakes are near the epicenters, while the 1979 earthquake has a dominant asperity $-60 \mathrm{~km}$ northeast of the epicenter. Presumably the 1906 earthquake ruptured all three asperities.
The Peru subduction zone has a slightly more complicated asperity distribution, but we have identified three main regions of concentrated moment release corresponding to the three earthquakes. The 1974 earthquake had a bilateral rupture along strike with most of the moment release constrained to the northwestern half of the aftershock area. Both the 1940 and 1966 earthquakes had one dominant asperity near their epicenters, though there was some moment release $\sim 80 \mathrm{~km}$ southeast of the 1966 epicenter. The Peru subduction zone may be capable of generating a multiple asperity rupture earthquake similar to the 1906 Colombia-Ecuador event.

We find no indication of the dominant asperities for the earthquakes overlapping along strike in any of these subduction zones. In fact the relocated aftershocks zones for the ColombiaEcuador and Peru zones do not overlap at all (Dewey and Spence, 1979; Mendoza and Dewey, 1984). In contrast, the aftershock areas of the large Kurile Islands earthquakes overlap significantly. Although the aftershocks along the Kurile Islands have not been relocated with the same method as for Peru and Colombia-Ecuador, it seems unlikely that all of the overlap along the Kurile Islands is the result of incorrect locations.

The Colombia-Ecuador and Peru zones both have evidence of two modes of rupture between successive earthquake cycles. Along the Kurile Island zone we have an example of a multiple asperity rupture earthquake and three single asperity earthquakes that all failed between 1958 and 1973. Clearly the entire zone was nearly ready to fail. When one asperity fails, what determines whether it will trigger the failure of an adjacent asperity? The center to center asperity separation for the single asperity events is $140-170 \mathrm{~km}$, but for the 1963 multiple asperity event the distance is 90-100 km (Beck and Ruff, 1987). This distance may determine if a region will break as a single asperity or trigger adjacent asperities in a multiple asperity rupture. The asperity separation for the Colombia-Ecuador zone is $140 \mathrm{~km}$. The asperity separation along the Peru subduction zone is 100 $\mathrm{km}$. Based on this distance we might expect one asperity to be able to trigger an adjacent asperity, as suggested by the historic earthquake record. 


\section{Acknowledgments}

This research was supported by grants from the National Science Foundation (P.Y.I./EAR8351515 and EAR-8407786 to L.J.R.). We thank J. Dewey for his unpublished location of the 1940 earthquakes and J. Dewey and Bill Spence for many useful discussions. The seismograms for the 1940 earthquakes were kindly provided by many station operators and James Taggart at the U.S.G.S. Alberto Giesecke provided information on the historic seismicity of Peru. We also thank David Carrier, Thorne Lay, Doug Christensen, Susan Schwartz and Chris Lynnes for their useful comments and discussions.

\section{References}

Abe, K., 1972. Mechanisms and tectonic implications of the 1966 and 1974 Peru earthquakes, Phys. Earth Planet. Inter., 5: $367-379$.

Astiz, L., Lay, T. and Kanamori, H., 1989. Large intermediate depth earthquakes and the subduction process. Phys. Earth Planet. Inter., in press.

Barazangi, M. and Isacks, B.L., 1976. Spatial distribution of earthquakes and subduction of the Nazca plate beneath South America. Geology, 4: 686-692.

Barazangi, M. and Isacks, B.L., 1979. Subduction of the Nazca plate beneath Peru: evidence from spatial distribution of earthquakes. Geophys. J.R. Astron. Soc., 57: 537-555.

Beck, S. and Ruff, L., 1984. The rupture process of the great 1979 Colombia earthquake: evidence from the asperity model. J. Geophys. Res., 89: 9281-9291.

Beck, S. and Ruff, L., 1987. Rupture process of the great 1963 Kurile Islands earthquake sequence: asperity interaction and multiple event rupture. J. Geophys. Res., 92: 1412314138.

Berninghausen, W.H., 1962. Tsunamis reported from the west coast of South America 1562-1960. Bull. Seismol. Soc. Am., 52: 915-921.

Bullen, K.E., 1963. An Introduction to the Theory of Seismology. Cambridge University Press, New York.

Chinn, D.S. and Isacks, B.L., 1983. Accurate source depths and focal mechanisms of shallow earthquakes in western South America and in the New Hebrides Island Arc. Tectonics, 2: 529-564.

Christensen, D. and Ruff, L., 1985. Analysis of the trade-off between hypocentral depth and source time function. Bull. Seismol. Soc. Am., 75: 1637-1656.

Christensen, D. and Ruff, L., 1988. Seismic coupling and outer-rise earthquakes, J. Geophys. Res., 93: 13421-13444.
Dewey, J.W. and Spence, W., 1979. Seismic gaps and source zones of recent large earthquakes in coastal Peru. Pure Appl. Geophys., 117: 1148-1171.

Ericksen, G.E., Plafker, G. and Fernandez, J., 1970. Preliminary report on the geologic events associated with the May 31, 1970, Peru earthquake. U.S. Geological Survey, Washington, DC, Geological Survey Circular, 639, 25 pp.

Gutenberg, B. and Richter, C.F., 1954. Seismicity of the Earth, 2nd edn., Princeton University Press, Princeton, NJ.

Hasegawa, A. and Sacks, I.S., 1981. Subduction of the Nazca plate beneath Peru as determined from seismic observations, J. Geophys. Res., 86: 4971-4980.

Hatori, T., 1968. Study on distant tsunamis along the coast of Japan. Part 2, tsunamis of South American origin. Bull. Earthquake Res. Inst. Univ. Tokyo, 46: 345-359.

Hatori, T., 1981. Colombia-Peru tsunamis that observed along the coast of Japan, 1960-1979. Bull. Earthquake Res. Inst. Univ. Tokyo, 56: 535-546.

Heck, N.H., 1947. List of seismic sea waves. Bull. Seismol. Soc. Am., 37: 269-286.

Isacks, B.L. and Barazangi, M., 1977. Geometry of benioff zones: lateral segmentation and downwards bending of the subducted lithosphere. In: M. Talwani and W.C. Pitman III (Editors), Island Arcs, Deep Sea Trenches and Back-arc Basins. Maurice Ewing Series, 1, American Geophysical Union, Washington, DC, pp. 99-114.

Kanamori, H., 1981. The nature of seismicity patterns before large earthquakes. In: D.W. Simpson and P.G. Richards (Editors), Earthquake Prediction, An International Review. Maurice Ewing Series, 4, American Geophysical Union, Washington, DC, pp. 1-19.

Kanamori, H. and McNally, K.C., 1982. Variable rupture mode of the subduction zone along the Ecuador-Colombia Coast. Bull. Seismol. Soc. Am., 72: 1241-1253.

Kelleher, J.A., 1972. Rupture zones of large South American earthquakes and some predictions. J. Geophys. Res. 77: 2087-2103.

Kelleher, J. and McCann, W., 1976. Buoyant zones, great earthquakes, and unstable boundaries of subduction J. Geophys. Res., 81: 4885-4896.

Lay, T., Astiz, L., Kanamori, H. and Christensen, D., 1989. Temporal variation of large intraplate earthquakes in coupled subduction zones. Phys. Earth Planet. Inter., 54: 258-312.

Lockridge, P.A., 1985. Tsunamis in Peru-Chile. World Data Center A for Solid Earth Geophysics, Report SE-39, pp. 97 , U.S. Department of Commerce, National Oceanographic and Atmospheric Administration, Boulder, C.O.

Lomnitz, C., 1971. The Peru earthquake of May 31, 1970: some preliminary seismological results. Bull. Seismol. Soc. Am., 61: 535-542.

Lomnitz, C. and Cabre, R., 1968. The Peru earthquake of October 17, 1966. Bull. Seismol. Soc. Am., 58: 645-662.

Lynnes, C.S. and Ruff, L.J., 1985. Use of the PP phase to study the earthquake source. Geophys. Res. Lett., 12: 514-517.

McCann, W.R., Nishenko, S.P., Sykes, L.R. and Krause, J., 1979. Seismic gaps and plate tectonics: seismic potential for major boundaries. Pure Appl. Geophys., 117: 1082-1147. 
Mendoza, C. and Dewey, J., 1984. Seismicity associated with the great Colombia-Ecuador earthquakes of 1942, 1958, and 1979: implications for barrier models of earthquake rupture. Bull. Seismol. Soc. Am, 74: 577-593.

Minster, J. and Jordan, T., 1978. Present-day plate motions. J. Geophys. Res., 83: 5331-5354.

Ruff, L., 1987. Tomographic imaging of seismic sources. In: G. Nolet (Editor), Seismic Tomography. D. Reidel, Dordrecht, pp. 339-366.

Ruff, L. and Kanamori, H., 1980. Seismicity and the subduction process. Phys. Earth Planet. Inter., 23: 240-252.

Ruff, L. and H. Kanamori, 1983. The rupture process and asperity distribution of three great earthquakes from longperiod diffracted $P$ waves. Phys. Earth Planet. Inter., 31: 202-230.

Schwartz, S. and Ruff, L., 1985. The 1968 Tokachi-Oki and the 1969 Kurile Islands earthquakes: variability in the rupture process. J. Geophys. Res., 90: 8613-8626.

Schwartz, S. and Ruff, L., 1987. Asperity distribution and earthquake occurrence in the southern Kurile Arc. Phys. Earth Planet. Inter., 49: 54-77.

Schweller, W.J., Kulm, L.D. and Prince. R.A., 1981. Tectonics, structure, and sedimentary framework of the Peru-Chile trench. In: L.D. Kulm et al. (Editors), Nazca plate: Crustal Formation and Andean Convergence. Geol. Soc. Am. Mem., 154: 323-350.

Silgado, E., 1985. Destructive earthquakes of South America 1530-1894. Center of Regional Seismology for South America, Ceresis, 10, $315 \mathrm{pp}$.

Stauder, W., 1975. Subduction of the Nazca plate under Peru as evidenced by focal mechanisms and by seismicity. J. Geophys. Res., 80: 1053-106.

Warsi, Waris E.K., Hilde, T.W.C. and Searle, R.C., 1983. Convergence structures of the Peru trench between $10^{\circ} \mathrm{S}$ and $14^{\circ} \mathrm{S}$. Tectonophysics, 99: 313-329.

Watanabe, H., 1968. Descriptive table of tsunamis in and near Japan. Jishin, 21: 293-313. 